\title{
From Tamil Pānar to the Bānas: Sanskritization and Sovereignty in South India
}

\author{
Sudalaimuthu Palaniappan
}

South Asia Research and Information Institute, Dallas, TX 75370-1531, USA; palaniappan@sarii.org

\begin{abstract}
Historians include the Bānas among the important minor dynasties of South India. They are first mentioned as Bṛhadbāṇas in the Tālagunda inscription of the fifth century. Rulers with the Bāna name existed up to the sixteenth century in the Tamil country. During their history, they also married into major dynasties like the Cōlas and claimed to be descendants of a lineage starting from Bali. Many historians have noted the semantic similarity between the term Bṛhadbāna and the earlier Tamil bardic Perumpānan of the Cankam literature. The historians, however, have not explicitly addressed the issues of whether the Bānas originated from the Tamil Pānar and why they chose to claim Purānic Bali to be their progenitor. In the present essay, based on an analysis of Cankam texts, and epigraphic data, it is shown first that the Bānas must have originated from the Tamil bards. Later, the reasons for the Bānas choosing to have Bali as the progenitor of their lineage are explored. It looks like Tamil bardic age values might have played a role in this.
\end{abstract}

Keywords: Pāṇar; Bāṇas; Tamil bards; Sanskritization; sovereignty

Citation: Palaniappan,

Sudalaimuthu. 2021. From Tamil Pānar to the Bānas: Sanskritization and Sovereignty in South India. Religions 12: 1031. https://doi.org/ $10.3390 /$ rel12111031

Academic Editor: Caleb Simmons

Received: 16 September 2021

Accepted: 12 November 2021

Published: 22 November 2021

Publisher's Note: MDPI stays neutral with regard to jurisdictional claims in published maps and institutional affiliations.

Copyright: (C) 2021 by the author. Licensee MDPI, Basel, Switzerland. This article is an open access article distributed under the terms and conditions of the Creative Commons Attribution (CC BY) license (https:/ / creativecommons.org/licenses/by/ $4.0 /)$.

\section{Origin of the Bānas}

\subsection{Introduction}

Historians include the Bānas among the important minor dynasties of South India. They are first mentioned as Bṛhadbānas in the Tālagunda inscription of the fifth century CE. Rulers with the Bāna name existed up to the sixteenth century in the Tamil country, where they were called the Vannar. In many of their inscriptions, they are said to belong to the lineage of Bali, an Asura ${ }^{1}$. During their history, they also married into major dynasties like the Cōlas. For instance, Vallavaraiyar Vandyadevar, the Bāna chief, married Kuntavai, the elder sister of Cōla Rājarāja I (South Indian Inscriptions, vol. 2, no. 6, p. 69). Earlier, Cōla Rājarāja I's father's sister, Ariñcikaip Pirātțiyār, was married to another Bāṇa prince (South Indian Inscriptions, vol. 13, no. 197, p. 107).

Many historians have noted the semantic similarity between the term Bṛhadbāna and the earlier Tamil name Perumpānan of the Cañkam literature. Pānar (plural of Pānann) were the bards of the Tamil country. These historians, however, have not explicitly addressed the issues of whether the Bānas originated from the Tamil Pānar and why they chose to claim Purānic Bali to be their progenitor.

The present essay consists of three parts. In this essay, I shall begin by discussing the role of bards in early Tamil society. Then, I shall look at what Tamil literary scholars have said regarding the origin of the Bānas vis à vis information from early Tamil literary texts and inscriptions in Tamil Nadu. Then, we shall explore if the early Tamil bards and warriors were from the same community. Next, I shall explore if descendants of some of the Tamil bards became chiefs called Pānans ruling over a territory called Pānātu in the northern part of Tamil Nadu. Then, I shall discuss the Tamil terms Perumpān and Perumpānan and the Sanskrit term Bṛhadbāna since some historians seem to believe that the name of the chief Pānan in the Cankkam literature was really a Tamilized version of Sanskrit Bāna. In order to determine whether Bṛhadbāna became Perumpāṇan or Perumpānn, I shall explore the dates of the poems in which these terms occur. Next, I shall look at linguistic and philological 
aspects of the sound variation from Pānar to Bāna to Vānar. Finally, I shall summarize the findings regarding the origin and movement of the Bānas over time.

In the second part, I shall consider the main features of early Tamil kingship. Then, I shall look at how Sanskritization impacted the Bānas' identity. Next, I shall explore why the Bānas chose to trace their lineage to Bali, an Asura, while other dynasties were claiming a descent from a sage or Sun or Moon. Since Bali had lost his sovereignty over his domain, we shall compare Bali's story with the story of Tamil chief Pāri, perhaps the best-known philanthropist of the early Tamil society to speculate if the bardic age values of duty towards the bards might have influenced the Bānas to choose Bali as their progenitor.

Finally, in the third part, I shall conclude with findings regarding the Tamil bardic culture, openness of the Tamil society that led to the formation of the Pānar dynasty, later dynastic shift, Sanskritization, and the adoption of a unique Purānic identity influenced by the old bardic values

\subsection{Bards in Early Tamil Society}

In the early Tamil society, there were many types of bards. The Pānar are the most frequently mentioned bards, who sang and played the $y \bar{a} \underline{\underline{l}}$ or lute. Other bards included the Porunar, who sang and played a drum called kinai or tatāri; the Kōtiyar, who played a drum called mulavu and acted in theater; the Akavar or Akavunar or Akavalar were the heralds, carried a slender divining rod, and sang on the battlefields; and the Viraliyar, who were females, who played the lute, and sang too. There were also other terms like the Cenniyar, synonymous with the Pānar; the Kinaiyar, synonymous with the Porunar; and the Kūttar, Vayiriyar, and Kannular, synonymous with the Kōtiyar. These bards did not form separate castes in the early Tamil society. They were a vocational/professional community. The differences in names referred to their functional differences. The Porunar, Pānar, and Akavalar visited and sang in praise of the battlefields of their patrons.

The bards were considered as possessing mutuvāy 'ancient truth or wisdom'. Puranānūuru 319.9 calls a bard mutuvāyp pāna 'bard having ancient truth or wisdom.' According to Palaniappan (2008, p. 42) bards had an important role in ensuring the auspiciousness and prosperity of the community. When the bards visited the kings and chiefs, they were given valuable gifts as seen in the following example in the translation of Puranānūru 29.1-5 by Hart and Heifetz (1999, p. 24).

During the day, may the bards crowd around the festive

sessions of your court and their dark heads and tangled hair

turn radiant with fragrant garlands of gold, beautifully

crafted of thin plaques fashioned in the shape of lotuses

tempered in the fire and threaded onto fine pounded wires!

The bards were also given elephants as gifts, as mentioned in the example below from Akanānū $\underline{r}$ 106.10-12.

the Pānan who gets an elephant whenever Cēliyan,

who has learnt faultlessly the art of war, and whose

army with shining swords kills in the battlefields

Tamil bards not only received gifts like gold ornaments and elephants, but they also received land. Puranānn̄ur $\underline{\text { 302 }}$ 302-7 mentions that the Tamil bards had received villages as gifts as given below.

kai vār narampin pānarkku ōkkiya

nirampā iyavin karampaic cīrū

the villages on poor land with narrow paths,

which were granted to the bards who pluck the strings with their fingers 
The bards had also received a bigger territory, as shown by Cirupānārrruppațai 109-11 as given below.

kurum porai nal nātu kōtiyarkku īnta

kārik kutirai kāriyoțu malainta

ōrik kutirai ōri...

The good country with small hills, which Ōri, whose horse was named Ōri and who fought with Kāri, whose horse was named Kāri, gave to the Kōtiyar ...

In a similar manner, the Pānar could have received some territory in the northern border area of the Tamil region, which could have become the base of the Pānar, who, as we will see, later became the Bānas.

Early Tamil poetry, known as the Cankam poetry, was modelled after the earlier oral poetry of the Tamil bards like the Pānar.

As Thani Nayagam (1995, p. 243) puts it,

The bards were so prominent and numerous members of early society and were so identified with panegyrics, that in subsequent development when poets compose panegyrics in praise of kings and chiefs they do so in a 'bardic convention', as if a bard were praising the hero of the poem.

However, it should be noted that, based on the names of the poets, there were poets of bardic origin, who have composed Cankam poems too. For instance, we find Netumpalliyattanār, a male, and Nețumpalliyattai, a female, both names meaning 'great one of many musical instruments' among the Cankam poets.

The Tamil bards played as important a role with respect to Tamil kingship as the Brahmin played with respect to the Indo-Aryan kingship in north India. Saskia KersenboomStory says the following regarding the Tamil bards' relationship with the Tamil kings.

While in the Indo-Aryan tradition the purohit (Brahmin priest) accompanies the king (rāja, nrpa-, bhūpa-, bhūpāla goptr-, nātha-,) on his chariot to the battlefield, his Tamil colleague the porunar and/or pānar (two types of bards) fulfill a similar function in the king's (kō, irai, iraivan $)$ following. Although the Brahmin (antanar) is known at the Tamil court, and respected, he does not play any role of significance to be compared with the bards. (Kersenboom-Story 1981, p. 32)

The Tamil situation may be considered the reverse of the Indo-Aryan. The IndoAryan king is steeped in Vedic and post-Vedic symbolism and ritualism due to which the Brahmins are of primary importance and far more indispensable than the panegyrists, genealogists and eulogists (mägadhas, sūtas). In contrast to the mythological equation of worldly power and (Vedic) cosmic power, the Tamil king lived for the immortality of glory ( pukal) of his forefathers, his clan and his own person. In this milieu of glorious death on the battlefield, worship of hero-stones, gruesome celebrations of Victory on the battlefield and of the conception of the 'world of heroes', the Tamil king was far more dependent on his bards who had the power to 'actualize' glory and thus to confer immortality. Their mutual tie was one of kațan 'sacred duty' which a king gladly fulfilled for his own sake as well as that of his forefathers and the entire clan. Cosmic equation by Vedic sacrifice was not on his mind; it was performed in course of time perhaps as a fashionable 'showing off' to his enemies. (Kersenboom-Story 1981, p. 33)

Auvai Turaicāmip Pillai stated in his introduction to the decad called "Pānan Pattu" (decad about the bard) in his commentary on the Cankam text, the Airikurunūru (p. 1030) that depending on the activities in which they are engaged, Pānar are denoted in texts by several names such as Pānar, Akavunar, Kūttar, Kōtiyar, Iyavar, and Porunar. That the same bard is addressed by different names can be seen in the Porunarārruppatai, a guide poem, in which a bard returning after having received rich gifts from a philanthropist encounters a 
poor Porunan and his family on the way looking for support from a philanthropist. The returning bard tells the poor bard the name and place of the patron, who gave him gifts. He also advises the poor bard to go to the patron and gives him directions to get to the patron's place.

In Porunarārruppatai, the poor bard is addressed as Poruna, Kōtiyar Talaiva 'leader of the Kōtiyar,' and Ëlin Kilava 'one who possesses seven musical notes' and the female accompanying the Porunan is called Pạtini, the female of the Pānar community, as given below. $^{2}$

vēru pulam munniya viraku ari poruna (Porunarārruppațai 3)

O Porunan knowing the appropriate conduct, who has sought different lands!

pātal parriya payan uțai elēal

kōtiyar talaiva (Porunarārruppațai 56-57)

O leader of the Kōtiyar, who has the lute, which provides musical enjoyment associated with songs!

elumati vāli ēlin kilava (Porunarārruppatai 63)

O owner of seven notes! Get up. May you prosper.

pețai mayil uruvin perum taku pātinini (Porunarārrruppațai 47)

the Pātinini, who is of excellent qualities and looks beautiful like a peahen!

Since Elin Kilavan is an expert in music based on seven musical notes, the term most probably should indicate a Pạnan, who is an expert in singing and playing the lute. Since ordinarily the Porunar are supposed to be players of the tatāri or kinai drums, and the Kōtiyar and Kūttar are supposed to be actors, the use of all three terms to address a single person means all these bards are from the same bardic community but only differing in their performative aspects. As the same person could perform as a singer in one instance and as an actor in another, one could be called a singer as well as an actor. ${ }^{3}$ Therefore, whatever we find regarding the life of the Porunar, Kōtiyar, and Kūttar will apply to the Pānar too.

In spite of their cultural importance and prominent role in the Cankam poetry, for more than a millennium, there has been an enormous misinterpretation regarding their status and role in the Tamil society. Some of the Tamil scholars have considered these bards to be of low caste especially during the medieval periods. ${ }^{4}$ This should be attributed to a lack of interdisciplinary approach to analyzing the cultural history of the Tamils as has been shown earlier (Palaniappan 2008, 2016). ${ }^{5}$ In fact, these bards continued to enjoy high esteem in the Tamil society as performing artists, right up to the advent of the Vijayanagara rule in the Tamil country.

However, scholars had not addressed how some of these bards also became rulers in their own right, later known as the Bānas, a dynasty with more than a millennium of history. This fact has important implications for addressing the question of whether the early Tamil society was open to members of different communities becoming rulers or it was varna-based to begin with. Palaniappan (2008, pp. 49-50) had used information from Sanskrit texts to explain away indirectly the mention of nārpāal 'four classes' in Puranānnūru 183.8-10 by Āriyappațaikațanta Nețuñceliyan 'the Pāṇtiyan Nețuñceliyan who defeated the Aryan army', who states the following:

And even among the four classes with difference known, if a person from a lower class becomes learned, even a person from a higher class will submit to him to study.

What Netuñaliyan refers to is the caturvarna (four classes) which was prevalent among the Indo-Aryan speakers of North India and was absent in the Tamil areas. In fact, according to Manu, the Sanskrit lawgiver, all the Tamils (Drāvidia) were Kṣatriyas who did not perform the Vedic rituals and, as a result, sank to the 
rank of Súdras. In this, they were similar to the Greeks, and Chinese in the eyes of the Brahmins. Netuñceliyan may have based his statement on a story such as the Bṛhad-āranyaka Upaniṣad story of Dṛpta-bālāki of the Gārgya clan and Ajātaśatru, the king of Kāśi. In this story, Dṛpta-bālāki, a Brāhmin, realizes that he lacks the knowledge of Brahman and seeks to become the pupil of Ajātaśatru, a Kṣatriya. (As his name suggests, it is likely Netuñceliyan has had encounters with the Aryan culture.)

What Manu says regarding the Tamils cannot be taken literally as the words of a historian. However, if every Tamil was a Kṣatriya, then there was no varna system among the Tamils and Manu may have inadvertantly alluded to the possibility of even a Tamil bard becoming a ruler of a territory! If it can be shown that a Tamil bard founded a ruling dynasty in early Tamil society, it will more directly and firmly establish the open nature of the society unconstrained by any birth-based social hierarchy.

\subsection{Tamil Scholars' Views on the Origin of the Bānas}

With respect to the origin of the Bānas, Auvai Turaicāmip Pillai made the following comments (as translated by me) in his introduction to the decad called "Pānan Pattu" in his commentary on the Cankam text, the Ainkurunūru (pp. 1028-29) ${ }^{6}$.

There were also pannar who were involved in the field of fighting and excelled in wrestling and protecting the country without learning music and theater. Among them, one called Pānann ruled the kingdom north of the river Pālār [Akanānn̄urru 113, 155, and 325]; Cankam poets praise saying 'in the north is the land of Pānan of the strong spear ${ }^{7}$; in that country, stone inscriptions mention Perumpānappātiti and Pānmalai situated on the northern bank of the Pālār river. His descendants lived as Vānar, Vānātirāyar, and Vānataraiyar. Their many inscriptions are in the Tiruvallam temple in the North Arcot taluk [South Indian Inscriptions, vol. 3, nos. 42, 43, 47 and 48]. In later times, they were spread all over the Tamil country; even those who were called Vānakōvaraiyar were also the descendants of the Pānañ. Another Pānan excelled in wrestling and flourished in the Cọla

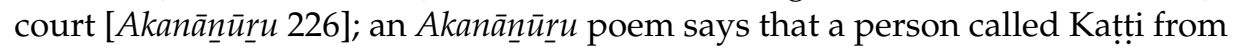
the region ruled by the Gangas [in Southern Karnātaka] came to wrestle against Pānan in the court of Veliyan Tittan and fled in fear as soon as he heard the sound of the kinai drum in the court preparing for battle [Akanānn $\underline{u} r u$ 226]; one Porunan from the Āriya country to the north of Kuțanătu, came with one Kanaiyan of Kuțtanātu to wrestle against Panan, but, being unable to withstand the strength of Pāṇan, lost making Kaṇaiyan shameful [Akanān̄ūru 386]. ${ }^{9}$

Following Auvai Turaicāmip Pillaai, literary scholars like Varatarācan $(1973$, p. 15) and Ilankumaran $(1987$, p. 141) considered the chief Pānan to be from the bardic community of Pānar.

\subsection{Bards and Warriors}

Views of Pillai notwithstanding, there is a notion held by some scholars that the Cankam period Tamil bards and warriors were from different divisions of the early Tamil society. This was articulated by Hart (1975, pp. 56-57) in the following words:

The [Cankam] anthologies seem also to show a society divided into two different parts: on the one hand, there are the uyarntōr, or "high ones", spoken of in the Tolkāppiyam, who are warriors and leaders of society and whose death is often commemorated by memorial stones; on the other hand, there are the ilintō $r$, or

"low ones", represented by the kinai and tuti drummers, the Pānan, the Vēlan, washermen, leather workers, and others.

Let us see if what Hart says has been true regarding the Tamil bards and warriors during the Cankam period and later. With respect to the skills of bards and warriors, it is 
not impossible for one to have both skills. In the famous Tanjavur temple inscription of the eleventh century CE, South Indian Inscriptions, vol. 2, no. 66, pp. 275-76, there are several members of the elite troops of Rājarāja I, who were given grants as musicians. These troops were selectively recruited into several elite military units named after different titles of the Cōla king such as Kșatriyasikhāmaṇi or Śatrubhujaṃka (Śatrubhujaṃa). These military units fell under the category of Terinta Valan்kai Vēlaikkārar meaning 'selectively recruited right hand troops who will die if they fail to protect the king'. For instance, Aiyāran Antari of the Alakiya Cōlat Terinta Valankkai Vēlaikkārar ${ }^{10}$ was a pakkavādyar or an accompanist who had belonged to the selectively recruited military unit called Alakiya Cōlat Terinta Valaṅkai Vēlaikkārar.

Here are some additional examples of pakkavādyar or accompanists:

- Catti Ārūr of Kṣatriyasikhāmaniit Terinta Valaṅkai Vēlaikkārar

- Catti Ponnnan of the Śatrubhujạ̣kat Terinta Valañkai Vēlaikkārar

Similarly, there were many gāndharvar or singers from these elite troops. Here are some examples of gāndharvar or singers.

- Mankkalavan Maṇi of Mūrttavikramābharanat Terinta Valankkai Vēlaikkārar

- Taṇtan Kampan of Mūrttavikramābharaṇat Terinta Valańkai Vēlaikkārar

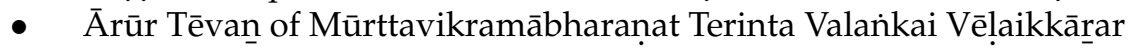

Clearly, musicians and warriors were from the same community in the eleventh century CE. This was not a new development in the medieval period. Even in the Cankam period, Tamil bards and warriors came from the same community. For instance, the Tamil word porunan $\left(<^{*}\right.$ poru 'fight') can refer to a bard or a warrior. In Puranānū $\underline{r} u$ 386.19, some bards are called porāap porunar 'non-fighting warriors. On the other hand, in Puranānūuru 17.13, atu poruna 'killing/conquering warrior!' is used by the poet to address the warriorking making it explicit that by the vocative 'poruna' the warrior-king is addressed and not a bard. ${ }^{11}$

In Cankam poems, the arms of warriors are often compared to concert drums (mulavus) as in Puranānū $\underline{\text { ru 88.6. }}$. Another example of such usage occurs in a Cankam text called the Maturaik Kāanci. This text is the longest narrative poem of the Cankam literature. It was authored by the poet Mānkuṭi Marutan to advise the Pāṇtiya king Nețunceliyan, who was the victor of the battle at Talaiyālankannam. It narrates all that goes on over a whole day in the Pạntiyan capital of Maturai (Madurai) and advises the king on what he should do to achieve fame like his ancestors and lead an enjoyable life. Maturaik Kãñci 99 uses the description mulavut tōl muran porunar meaning 'bards of fight with arms like concert drums' to describe some bards who receive gifts typically given to bards such as elephants and

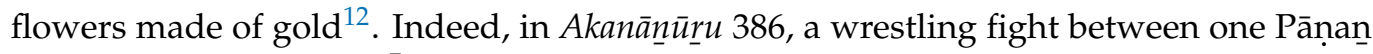
and a Porunan from the Āriya land is discussed. Here, Pānan is described as having arms like concert drums and he kills his opponent. In Akanānūuru 226.13-17, Kații, a chief, came to fight Pānann, a warrior, who was in the court of the Cōla king Tittan Veliyan. However, after hearing the sound of the drum in the Cōla court, Katṭi fled without fighting. ${ }^{13}$ Finally, Akanānū $\underline{\text { r } u} 189.5$ employs the word mallar to refer to bards. Everywhere else in the Cankam literature, mallar has been used to refer to warriors. ${ }^{14}$ So, the bards must be from the same community as the warriors and there was no division between warriors and bards in the society as postulated by Hart.

\subsection{Bards as Chiefs}

That descendants of some Tamil bards were not only warriors but also chiefs can be

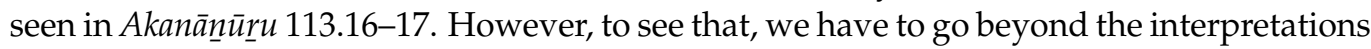
of some past scholars to obtain a philologically accurate interpretation. Wilden (2018)'s translation offers the latest interpretation of these lines as given below.

Vilavu ayarntannna kolum pal titti $i^{15}$

elāap pānañ nal nātțu umpar 
beyond the good land of the bard who does not rise

from many rich snacks as if engaged in a feast

The problem with this translation is that it takes pannan 'bard' to be an ordinary resident of the land. Wilden has not compared the present text pānan nal nătțu with the text nal vēl pānan nal nāțtu in Akanāñūru 325.17 meaning 'in the good land of Pānan with the good spear,' where Pānan is clearly a warrior and not a bard. Moreover, in every instance in which the text ' $x$ nal nāttu' has been used in the Cankam literature, where $x$ is a masculine singular person, $x$ is always a ruler and not just an ordinary resident. Here are a few examples. Āay nal nātțu (Akanān̄ūru 198.14), 'Erumai nal nāțțu' (Akanān̄ū r- 253.19), 'Pulli

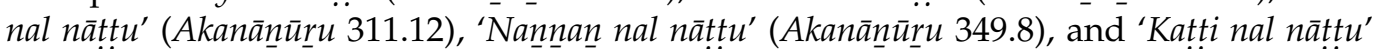
(Kuruntokai 11.6). It should be noted that Āay, Erumai, Nannan, Pulli, and Kați were all chiefs. So, Pānan should have been a chief as well. We also know that these names represent a generic name of a lineage of chiefs, best exemplified by Āy in whose lineage we have Ây Aṇtiran and Āy Eyinan (Pilllai 1967, p. 1463). (The extra ' $a$ ' in Âay is inserted due to metrical reasons.) Wilden also has taken ela $a$ to be the negative adjectival participle of $e \underline{l} u$ 'to rise' (DEDR 851). Other scholars have interpreted the word differently.

Rākavaiyañkār and Irājakōpālāryan, in their Akanānūụru edition of 1933, interpret elāap pānan as 'Pānann, who does not rise to fight those who flee from battle. In contrast, Nātțār and Pillai in their Akanānnūru edition of 1946 interpret elāap pānan as 'Pānan, who does not flee from enemies.' Such different interpretations arise due to the difficulty of making sense of $e \underline{l} a \bar{a}$, considered by these scholars as deriving from DEDR $851 e \underline{e} u$ 'to rise'. Tamil $e \underline{l} u$ 'rise' also has a homophon given by DEDR 5156 which has cognate words such as yāl, ñă $\underline{l}$,

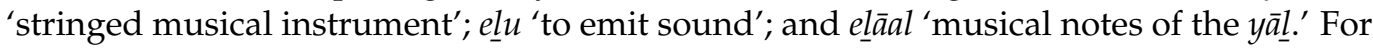
the affirmative use of eli $\bar{i} i$ in the sense of bards making music, see Patirruppattu $29.7-8 .{ }^{16}$ So, if elāa in elāap pannan is derived from DEDR 5156, it means 'the bard who does not play the lute/make music'. ${ }^{17}$ This leads to the following translation of Akanānūru 113.16-17.

beyond the good land of Pānan, who does not make music,

with many rich meat foods as if engaged in a feast

Here, 'Pānan, who does not make music' makes it explicit that the poet is talking about a chief and not a bard. Not realizing the use of Velippatai technique in this poem involving $\underline{e l} u$ of DEDR 5156, which gives a clear and direct meaning, the above-mentioned scholars have given widely diverging interpretations of elāap pānan. Wilden's interpretation, however, is partly right in that the origin of the chief is connected to a bard.

That the Pānar were also chiefs or warriors is brought out by Kuruntokai 328, which has been misinterpreted by scholars who thought that the Pānar had functioned only as musician bards. Consider the text below.

... alarē

vil kelu tānai vicciyar perumakan

vēntaroțu poruta ñāñraip pānar

puli nōkku ural nilai kaṇta

kali kelu kurumpūr ārppinum peritē

(Kuruntokai 328.4-8)

The gossip was louder than the roar of the noisy village in the arid tract, that saw the stance of the Pānar that resembled the look of the tiger, when the chief of Vicciyar of army abounding in archers fought against the kings. ${ }^{18}$

The Pānar in this poem should be interpreted as chiefs or warriors and not as bards based on philology. In all other occurrences of 'pānar' in Classical Tamil literature, pānar is mentioned with one or more of their usual attributes such as given below.

- The bard's musical instruments; 
- The bard's performance/music/song;

- The bard's poverty;

- The bard's hunger;

- Gifts received by the bard such as food, clothes, elephants, gold flower, and land;

- The bard's mantai, a vessel, in which they received food;

- The bard's patron;

- The bard's large entourage of relatives.

Kuruntokai 328 is the only exception where none of the above attributes is mentioned. The only attribute given to these pānar is their 'puli nōkku' (fierce look). ${ }^{19}$

It should also be noted that the Cankam poems also use plural forms like Cōlar, Āriyar, and Vicciyar to denote multiple members of a dynasty or the members of a dynasty's army as given in the example below.

māri ampin malait tōl cōlar

vil iṇțu kurumpin vallattup puramilai

äriyar pataiyin uțaika ...

(Akanān̄ūru 336.20-22)

'Like the army of the Aryan kings at the external protective forest of Vallam strengthened by the bows of the army of the Cōlas with rain-like arrows, cloudslike shields'

Here, 'Cōlar' really signifies the army of the Cōlas. Vallam most probably refers to the town called Tiruvallam, the capital of the Bānas in Perumpānappāti several centuries later.

That is why the Pānar in Kuruntokai 328 cannot be taken to be functioning as bards but as chiefs or warriors with the fierce look of a tiger. These "Pānar' chiefs or warriors must have been involved in fighting.

Therefore, Auvai Turaicāmip Piḷai is right in characterizing a section of the Pānar community as being chiefs and warriors. However, Turacicāmip Pillai is wrong to interpret the name Pānan as the given name of a person who founded this dynasty as he states in his commentary on Narrinai 148. Pānan represented the generic name of a member of the dynasty of Pānar in Akanān̄ ūru 113, 155, and 325 in the same way names like Celiyan, Cēral, and Cempiyan are dynastic names, which stand for individual kings of those dynasties in Akanānū $\underline{-}$ u 36.13-20. We really do not know who the originator of the dynasty was.

\subsection{Is 'Pānann' (The Name of the Chief) from 'Pānañ' or 'Bāna'?}

In terms of meanings referring to people, the Tamil Lexicon glosses Pān as 'Pānar caste' and Pānan as 'an ancient class of Tamil bards and minstrels.' However, philologically, the word just means Pānar, i.e., the plural of Pānan as can be seen in Puranān̄ū rַru 348.4, where pāncềri (< pān 'bards' + cēri 'street') is used to refer to the street, where the bards live. The Tamil Lexicon also glosses Pānan as a Tamil rendering of Sanskrit Bāṇa, an Asura devotee of Śiva. How can we determine if the name of Pannan, the ruler, is etymologically related to Pānan, the bard, or is a Tamilized form of Sanskrit Bāna? The use of the verb ellu of DEDR 5156 etymologically connected to making music in Akanān $\underline{u} \underline{r} u 113.17$ in connection with the chief Pānan makes it clear we are not talking about a Tamilized form of Sanskrit Bāna. There is also additional evidence from a Sanskrit text that there was a territory named after Pānar.

The reluctance of historians to identify the Pạnan, the chief, whom they identify as belonging to the Bāna dynasty, with the bardic community of Pănar is due to the implied assumption that the Cankam poems are Tamilizing the word Bāna as Pạnan because Tamil orthography has no separate character to denote the initial voiced obstruent ' $b$ ' of Bāna. So, instead of voiced ' $b$ ' the Tamil poets are assumed to have used the Tamil character representing voiceless ' $p$ ' resulting in Pāna. The final ' $\underline{n}$ ' in Pānān results from the process of adding the masculine singular suffix to the Sanskrit name Bāna giving us the full name of the chief, Pānan. 
This unstated assumption seems to be behind historians like Vētācalam (1987, p. 5), who has identified Pānann, the chief mentioned in Akanān̄ūru 113 and Akanān̄ūru 325, as belonging to the Bāna dynasty. However, they did not identify the chief as connected to the ancient bardic community of the Pānar. ${ }^{20}$ This unstated assumption is also revealed by what Venkatesan (Epigraphia Indica, vol. 42, p. 175) says in connection with a sixthcentury inscription from Paraiyanpattu in Gingee taluk in former South Arcot district. The inscription mentions a Jain teacher Vaccananti from Pānātu. Venkatesan says,

"The territorial division viz., Pānāọu, is in all probability, the same as Bānạụu i.e., the nādu of the Bānas. (emphasis mine) The Bāṇas were an ancient line of kings, who also ruled a portion of the Tamil country. This is the earliest so far known inscription, which mentions their territorial division as Pānāụ. The names Vānagōppādi-nāọu and Perumbāṇappādi, etc., are employed in the Tamil inscriptions of the latter period to indicate the territory of the Bānas. This territory probably formed the southern portions of the modern North Arcot District and probably also a portion adjacent to it in the South Arcot District. The village Mēlvaṇnakkambādị, possibly the corrupt form of Mēlvānagōppādị, may have been the western boundary of Vānagōppāḍi, and the village Kīlvaṇnakkambāḍi near Dēvikāpuram may have been the eastern boundary of the same division. The provenance of our inscription viz., Paraiyanpattu was well within the Bāna territory."

One has to note that the name Bānāẹu is not attested anywhere in texts or inscriptions. It is simply an assumption by Venkatesan that Bāṇạdu was the original form and Pānāọu was the Tamil rendering of it. Fortunately, we have clinching evidence from a Sanskrit text that resolves the issue.

Discussing the occurrence of pānātțu in the Paraiyanpattu inscription, Mahadevan (2003, p. 629) says that pānātțu is an oblique form of pānățu and that Pānāṭu is a compound made of $p \bar{a} n$ and $n \bar{a} t \underline{u}$. He further explains:

Cf. LT palvayin payanirai cernta pānātțu ānkaṇ. 'there in Pānātu where at many places milch cows gather' (Aka. 155:6-7). pānătțu is taken to be the sandhi of pān + natt $u$ and also interpreted as 'in the country of the pānan, by R. Raghavaiyangar $(1933)^{21}$ and by N. M. Venkataswamy Nattar and R. Venkatachalam Pillai (1949) in their editions of $A k a n \bar{a} \underline{n} \bar{u} \underline{r} u$, even though some old manuscripts give the variant reading pāl nātțu (> pāṇāttu) 'the ruined country' which does not suit the context. (I am grateful to Dr. S. Palaniappan, Dallas, USA, for the references. I consulted the unpublished notes of U. Ve. Swaminathaiyar at the Swaminathaiyar Library. While noting the reading $p \bar{a} \underline{l} n \bar{a} t \underline{t} u$ in Aka. 155, he has given cross-references to verses 113 and 325 referring to pänan nal nāttu 'in the good country of the pānañ'.) The present early inscriptional reference to $p \bar{a} n \bar{a} t \underline{t} t u$ is a valuable confirmation of the correct reading and interpretation of the expression. ${ }^{22}$

Mahadevan has not pointed out an important explanation regarding Akanānn̄ū 155 by Rākavaiyañkār and Irājakōpālāryan in their 1933 edition. As Mahadevan has noted, they interpret $p \bar{a} n$ in $p \bar{a} n \bar{a} t \underline{t} u$ as Pānan. However, in order to buttress their interpretation of singular Pānan, they cite the use of pānvaravu in Purapporul Venpāmālai 12.30, describing the theme of the arrival of a Pānan as a messenger in love poems. However, we have noted already that in the Cankam poems, Pān is a synonym of plural Pānar. This means pānātu means 'the land of the Pānar' referring to the country of the dynasty of the Pānar. ${ }^{23}$ In any case, what is important here is that Rākavaiyañkār and Irājakōpālāryan have related the Pānar dynasty to the bards.

The same connection is provided by a Sanskrit text. According to Lewis Rice (Epigraphia Indica, vol. 14, p. 334):

... the manuscript of a Digambara Jain work in Sanskrit, named Lōkavibhāga, has been discovered by the Mysore Archaeological Department (see the reports 
for 1909 and 1910), treating of Jaina cosmography. The contents, it says, were first delivered by the Arhat Vardhamāna, and handed down through Sudharma and a succession of other teachers. The Rishi Simhha-sūri (or Siṃha-sūra) produced the work in a translation (? From Prākrit into Sanskrit). And the Muni Sarvanandin formerly (purā) made a copy of it in the village named Pātalika in the Pānarāshtra. The interesting point is that the precise date is given when this task was completed, namely the 22nd year of Siṃhavarman, the Lord of Kāñchī, and is 80 beyond 300 of the Śaka years ... Pătalika, the village in which Sarvanandin made his copy, may be Pătalīpura, in the South Arcot District. The Periya-purānam makes it the seat of a large Jaina monastery in the 7th century. Pānarāṣhțra is no doubt the territory of the Bāna kings.

According to Jain (2007, p. 132), Lokavibhāga of Sarvanandi belonged to the sixth century CE. We also know that the sixth-century Paraiyanpattu inscription mentions the oblique form of Pānātu $(<p \bar{a} n+n \bar{a} t u)$. The first part $p \bar{a} n$ - in Pānātu refers to the bardic community of Pānar, whose adjectival form is Pāna. The latter part of Pānātu, -nătu, means 'country'. It is well-known that Tamil nātu is translated as rāsțra in Sanskrit. For instance, in Patțattālmañkalam plates of Pallava Mañkalanātu in Tamil is translated as Mañgalarāștra in the Sanskrit portion (Epigraphia Indica, vol. 18, pp. 1925-26, 116). Similarly, Larger Sinnamanur Grant renders Tamil Vațakalavali Nāțu as Vațakalavali Rāșța in Sanskrit (South Indian Inscriptions, vol. 3, Parts 3 \& 4, pp. 459, 462). Similarly, Muṇ̣a Rāsțtra was the Sanskrit name of Munḍa Nādu comprising part of Nellore District of erstwhile Madras Presidency (Epigraphia Indica, vol. 29, p. 94, n.2). Scholars also consider Vengorāștra in Māngalūr copper plates refers to Vènki Nātu or Vēngi kingdom (The Tamil Varalatru Kazhagam 1966, pp. 292-93). So, what we have in Pāna-rāsțra is a translation into Sanskrit of Pānātu, the country of the Pānar and not the Bānar. After all, Sanskrit with the separate phoneme of ' $b$ ' could have rendered the name Bāna-rāsțra, if indeed the original name of the rulers was Bāna. ${ }^{24}$ However, we should note that while the name Pānātu has remained the same for about six centuries, the extent of the territory covered by the term over this time period could have fluctuated widely.

We have shown that a dynasty founded by the Pānar, the Tamil bards, had been established in the northern part of the Tamil country. Next, we have to determine whether the Pānar dynasty and the Bānas are one and the same.

\subsection{Perumpān versus Brhadbāna}

Historians also make another assumption regarding the origin location of the Bānas, i.e., they originated north of the Tamil country and progressively moved south into the Tamil land. For instance, Vètācalam $(1987$, p. 5) states that one could say that the Bānas' political life began under the Sātavāhanas near Kurnool and Kolar regions, presently in Andhra Pradesh and Karnataka, respectively.

T. N. Ramachandran, the historian, states (Ramachandran 1931, pp. 300-302):

References to the Bānas are made in inscriptions dating from very early times. The earliest mention is in the Talagunda inscription of the Kadamba king Kakusthavarman (430-450 A.D.) in which it is said that Mayūraśarman, the first Kadamba king (345-370 A.D.) was helped by an ally of his called "Bṛhad Bāna" in his fight with the Pallavas in the forests of Sri Parvata and that he levied tribute from this "Bṛhad Bāna" as well as from other kings ${ }^{25}$. It would appear that the territory of this "Bṛhad Bāna" was very near Śrī Parvata, i.e., the present Śrīsailam in the Kurnool District...

The term "Bṛhad Bāna" in the Talagunda inscription corresponds to the Tamil term Perum-B̄anna of the territorial term Perum-bānappādi. It was by the latter term that the Bāna dominions were denoted ...

According to tradition the Bāna capital was known as Parivipuri, whose other forms were Prapurī, Parvipura, Parivai, Parvai, Parvi, Parivaipura, Parivipurī and 
Parigipura. Indeed, the last term, Parigipura, has led the late Rai Bahadur Venkayya to identify it with Parigi in the Hindupur Taluk of the Anantapur District. The claim of Tiruvallam in the North Arcot District for the Bāna capital, inasmuch as it was also known by the appellation Vannapuram, is easily explained by him as merely meaning that Tiruvallam was one of the important towns, if not the capital, of the Bāna territory. Long after the Bānas had ceased to rule, their scion, wherever they were, claimed to be lords of Parivipura and of Nandagiri, another equally important place. Nandagiri is the present Nandi-drug in the Chikballapur Taluk, Kolar District, Mysore. The fact that most of the inscriptions of the Bānas have been found in the Arcot, Kolar, Anantapur, and Kurnool districts makes one believe that the term Perumbānappādi which denoted the Bāna territory was applied to the large tract of territory with Śrisailam in the north, Kolar and Punganūr in the west, Kālahasti in the east and the river Pālār in the south. In the north they appear to have been the governors of the Pallava territory till the latter were driven down by the western Cạlukyas in the latter part of the 6th century A. D ...

... The rise of the western Câlukya power in the 7th century acted as a check not only to the Pallava power in the Telugu country but also to that of the local Bānas who appear to have guarded the Pallava territories there. Consequently, the Bānas, as Venkayya supposes, were forced into the northern portion of the North Arcot district...

Thus, according to Ramachandran and Venkayya, the Bānas were non-Tamils, originally hailing from the Telugu-Kannada region north of Tamil Nadu. They migrated to the Tamil country as a result of the pressure from the Western Cạlukyas. However, Chopra et al. $(1979$, p. 32) state that Mayūraśarman of the Kadamba dynasty "is known to have levied tribute from the subordinates of the Pallavas particularly the Brihadbanas who are known to Tamil Sangam literature as the Perumbanar." ${ }^{26}$ One will notice that Chopra, Ravindran, and Subrahmanian do not explicitly state that the Bāna dynasty descended from the bardic community of Pānar.

However, in the Tamil Cankam literature, Perumpān occurs in Narrinai 40.3 and Maturaik Kāñci 342 and Perumpānan occurs in Kalittokai 96.35. In all three occurrences, Perumpān or Perumpannan refers to the bardic community of Pạnar. If one can establish the dates of occurrence of Pānan as a chief and Perumpān in these Cankam poems as preceding the occurrence of Bṛhadbānas, then one can argue that 'Bṛhadbāna' is only a translation into Sanskrit of 'Perumpān.' We can look at Tamil philology and Indian epigraphy to explore this issue.

\subsection{Dates of Tamil Texts with the Occurrence of Chief 'Pānan' or Perumpān}

Akanānnūru 325 was authored by the poet Māmūlanāar. Regarding his date, Zvelebil (1975, p. 276) says, "There is unfortunately not a single reference giving a direct clue to his exact date; but by inference we may date him ca. 245 A.D." Zvelebil has obviously missed an important reference regarding his date. Akanān $\underline{n} \underline{u} u$ 31.14-15, also authored by Māmūlan̄ār, are given below followed by their translation.

tamil kelu mūvoar kākkum

moli peyar tēetta pan malai irantē

crossing the many mountains of the land, where the language changes, which the three kings with Tamil nature (Cēra, Cōla, and Pāntịya) protect ${ }^{27}$

What Māmūlan̄ār talks about in these lines is the northern border region of the Tamil country, north of which the spoken language changes from Tamil to Telugu or Kannada. The most interesting fact brought about by these lines is that the border region is protected by all three Tamil kings even though only the Cēra and Cōla lands adjoin the northern border. The Pāṇtiya kingdom lies south of the Cōla land. This means that Māmūlañār is 
referring to a confederacy of Tamil kings which also is mentioned by the Hathigumpha inscription of Khāravela (mid-first century BCE) who claimed to have broken up the confederacy (Thapar 2002, pp. 211-12). ${ }^{28}$ The confederacy was supposed to have lasted for 113 years (Epigraphia Indica, vol. 20, p. 88). ${ }^{29}$ The existence of the confederacy is also suggested by some Cankam poems as given below.

potumai cuțtiya mūvar ulakamum

potumai inzi ānțicinōrkkum

(Puranān̄ūru 357.2-3)

even for those who ruled without sharing

the land to be shared in common by the three (kings)

... valuti

tạ tamil potu enap porāan ...

(Pưranān̄ūru 51.4-5)

... The Pāntiyan king Valuti

will not tolerate the statement that the cool Tamil land is common (to Cēra, Cōla, and Pāṇtiya kings)

Since Māmūlanār uses the non-past tense form kākkum 'protect' to describe the action of the confederacy, it was in existence when he authored the poem. So, Māmūlan̄ār must have lived in the first century BCE before Khāravela broke it up. This means that Pānan, the chief, mentioned by Māmūlanār in Akanānūur 325 and the territory ruled by him, Pānan nal nātu or Pānātu,u, must have existed at that time, if not earlier.

As for the occurrence of Perumpān in Maturaik Kāñci 342, Zvelebil (1975, p. 273) dates the Maturaik Kãñ ci to ca. 215 CE. Since Tạlagunda inscription of the fifth century is the only inscription mentioning Bṛhadbāna, Bṛhadbāna seems to be the translation of Tamil Perumpān. To confirm this, we shall look at Dravidian linguistic data as well as the inscriptions mentioning the Bānas as they first shifted out of Tamil areas to Telugu and Kannada areas and moved back to the Tamil area later.

\subsection{Pānar Dynastic Movement}

Next, we consider the question of how the Pānar rulers geographically moved over time. The original home of the Pānar rulers, Pānātu, was in the Tamil country in the first century BCE. The place name had persisted up to the sixth century $\mathrm{CE}$, as shown by the Paraiyanpattu inscription. However, between these two timepoints, major movements of people had taken place. Kalabhras north of the border of Tamil country moved into the Tamil country. ${ }^{30}$ A branch of the Tamil Cōlas established themselves in Andhra as the Telugu Cōlas of Rēnāṇ̣u or Rēnāḍu.

H. Krishna Sastri, in his discussion of Mālēpāạu copper plates of Punyakumāra, a Telugu Cōla of the seventh century $\mathrm{CE}^{31}$, says the following (Epigraphia Indica, vol. 11, pp. $339,344-45)$.

After an invocation to Śiva, the record introduces us to a king Nandivarman of the Kāśyapa-gōtra. He was born in the family of Karikāla who was "the (celestial) tree mandāra on the mountain Mandara-the race of the Sun, the doer of many eminent deeds such as stopping the overflow over its banks of the (waters of the) daughter of Kavēra (i.e., the river Kāvēri), who made his own the dignity of the three kings (of the South) ..." 32

K. A. Nilakanta Sastri has discussed many Telugu Cōla records collected in 1947-1948 from Anantapur and Cuddapah districts (Epigraphia Indica, vol. 27, pp. 220-51). On paleographical grounds, these records of the Rēnandụ Chōlas range from the second half of the sixth century to the end of the eighth century CE. (Epigraphia Indica, vol. 27, p.220). 
He further says, "We have therefore to assume the existence of the Telugu-Chōlas in the Telugu country earlier than the Pallava conquest of the Chōla country of the Kāvēri basin." (Epigraphia Indica, vol. 27, p. 247).

One of the records of these Telugu Cōlas is the Chāmalūru inscription of Prthvīvallabha Vijayāditya Cōla (Epigraphia Indica, vol. 27, pp. 242-44) found in the village of Chāmalūru in the Jammalamadugu taluk. This inscription mentions a Bāṇa as Vānarāja, who was ruling at ca. 750 CE in Pāmbuliggi possibly identified with Hāvalige in the Gooty taluk in Anantapur District. Sastri writes in connection with this inscription (Epigraphia Indica, vol. 27, p. 243):

It would be of interest to trace here the activities of the Bānas during the period prior to their subjugation by the Telugu Chōla Vijayāditya of the present record. Several inscriptions of Châlukya Vijayāditya found in the locality around the place where the present record has been discovered, mention a number of Bāna chiefs ruling over this region ... The Perbāna family to which some of these Bānas of the Ceded Districts are stated to belong, may have, as their family name indicates, belonged to the Brihad-Bāna line, the foes of Kadamba Mayūraśarman, mentioned in the Talaguṇ̣a inscription of Kākusthavarman.

Additional inscriptions mentioned by Sastri (Epigraphia Indica, vol. 27, 243) include one of 719 CE at Koṇụpaḷi in Anantapur District of Vikramāditya Bali Indra Bāṇarāja, son of Balikulatilaka Narasiṃha Bāṇādhirāja and one of Western Cālukya Vikramāditya I (eighth century) at Arakațavēmula in Cuddapah district. Additionally, the Sāliggāme grant of the Ganga king Konguni Muttarasa of the eighth century from Nandaguḍi in Bangalore district mentions a Bāna chief by the name Perbbāṇa Muttarasa (Annual Report for the Mysore Archaeological Department for the Year 1941, pp. 132-33). Annual Reports on Indian Epigraphy (no. 418 of 1940-1941) from the eighth century of the Western Cālukya king Kīrttivarma Satyāśraya (II) from Korrapāḍu in Jammalamadugu taluk in Cuddapah district registers a gift of land made by Per-Bānāāhirāja. A Tamil herostone inscription in Pāppampāṭi in Dharmapuri District (fifth century CE) mentions a Bāṇa chief Vānaperumaraicaru as dying in a fight with the Ganga ruler in the 4th regnal year of Kōvicaiya Viṇnaparuman(Tarumapuri Kalvettukal (Mutal Tokuti), p. 57). ${ }^{33}$ Another herostone inscription (fifth or sixth century CE) in the same location mentions possibly the same Bāna chief as Vānaparuma araicaru (meaning Bāṇavarma Rāja) (Tarumapuri Kalvețtukal (Mutal Tokuti), p. 56). A Tamil herostone inscription in Cantūr in Krishnagiri district during 7th regnal year of Pallava Mahendravarman I (597 CE) mentions a Perumpānavilavaraicar. ${ }^{34}$ Another herostone inscription of 18th regnal year of Mahendravarman I in Tantampattu in Cenkam area in Tamil Nadu mentions a Bāṇa chief named Perumpāṇaraicar (Cerikam Națkarkal, no. 1971/77). A herostone inscription of ca. 697 CE set up in Tā. Vẹlūr in the Cenkam area during Pallava Narasimhavarman II's rule mentions a Bāṇa chief by the name Vānakōo Atiraicar (Ceñkam Națukarkal, no. 1971/54). Another herostone of ca. 705 CE in Tālaiyūttu in the Cenkam area in Tamil Nadu mentions a Bāna chief named Perumpānatiyaraicar set up during the same Pallava Narasimhavarman II's rule (Cerikam Natukarkal, no. 1971/73). A herostone inscription from the 30th regnal year of Kațānaiparuman of the eighth century CE in Cantūr in Krishnagiri District mentions a Perumpaṇilavaraicar (Kiruṣnakiri Māvatțak Kalvețtukal, p. 28). Five years later under the same ruler, another herostone inscription from the same location mentions a Pānilavarai[*car] (Kiruṣnakiri Māvatțak Kalvețtukal, p. 30). ${ }^{35}$ The Rāyakkōtṭai copper plates of Skandaśișya (a possible enemy of Nandivarman Pallavamalla) mentions a Mahāvalivāṇarājar (The Tamil Varalatru Kazhagam 1966, p. 104). The Pullūr copper plates of Nandivarman Pallavamalla mentions Bāṇādhipa (The Tamil Varalatru Kazhagam 1966, p. 186). Thus, we see that in the Tamil area, Vāna-, Perumpān-, and Perumpāna- occur interchangeably at least from the sixth century. Even during the Cankam period, some kings had the prefix Peru- and others did not. A ninth-century herostone inscription of Pallava Kampavarman in Kịlputtūr in Chingleput district of Tamil Nadu mentions a person by the name Perumpānan Cakkați Araiyar (South Indian Inscriptions, vol. 12 , no. 102, p. 46). 
The following table summarizes all the epigraphic data regarding the Bānas we have discussed above.

The locations of inscriptions included in Table 1 are shown in Figure 1. The distribution of Perbāna- or Perbbāna- components in Bāna names in non-Tamil areas not earlier than the fifth century and the names Perumpān or Perumpānan in Tamil areas from approximately $215 \mathrm{CE}$ to the ninth century confirm the direction of borrowing for Bṛhadbāna, i.e., Perumpāṇ or Perumpānanan > Bṛhadbāṇa.

Table 1. References to the Bānas in Various Inscriptions.

\begin{tabular}{|c|c|c|c|c|}
\hline Number & Date & Local Language & Place & Name \\
\hline 1 & fifth century & Kannada & Tālagunda, Shimoga district ${ }^{36}$ & Bṛhadbāṇa \\
\hline 2 & fifth century & Tamil & $\begin{array}{c}\text { Pāppampāti, Dharmapuri } \\
\text { District }\end{array}$ & Vāṇaperumaraicaru \\
\hline 3 & fifth or sixth century & Tamil & $\begin{array}{c}\text { Pāppampāṭi, Dharmapuri } \\
\text { District }\end{array}$ & Vāṇaparuma araicaru \\
\hline 4 & sixth century & Tamil & Cantūr, Krishnagiri District & Perumpāṇavilavaraicar \\
\hline 5 & seventh century & Tamil & Taṇtampaț̣u, Cenkkam area & Perumpānaraicar \\
\hline 6 & seventh century & Tamil & Tā. Vēḷūr, Ceṅkam area & Vāṇakōo Atiraicar \\
\hline 7 & seventh century & Telugu & $\begin{array}{c}\text { Arakațavēmula, Cuddapah } \\
\text { District }\end{array}$ & Perbāṇa vaṃśa \\
\hline 8 & eighth century & Tamil & Tālaiyūttu, Ceñkam area & Perumpāṇatiyaraicar \\
\hline 9 & eighth century & Tamil & Cantūr, Krishnagiri District & Perumpāṇilavaraicar \\
\hline 10 & eighth century & Tamil & Cantūr, Krishnagiri District & Pānillavarai[ $\left.{ }^{*} \mathrm{car}\right]$ \\
\hline 11 & eighth century & Tamil & $\begin{array}{c}\text { Rāyakkōtțai, Krishnagiri } \\
\text { District }\end{array}$ & Mahāvalivāṇarājar \\
\hline 12 & eighth century & Tamil & Pullūr, North Arcot District & Bāṇādhipa \\
\hline 13 & eighth century & Tamil & $\begin{array}{l}\text { Tiruvallam (Vānapuram), } \\
\text { North Arcot District }\end{array}$ & $\begin{array}{l}\text { Mahāvalikulotbhava } \\
\text { Śrīmāvalivānarāyarar, } \\
\text { Mahāvalivāṇarāyar }\end{array}$ \\
\hline 14 & eighth century & Telugu & Chāmalūru, Cuddapah District & Vāṇarāja \\
\hline 15 & eighth century & Telugu & $\begin{array}{l}\text { Kondupalụi, Anantapur } \\
\text { District }\end{array}$ & Bāṇarāja \\
\hline 16 & eighth century & Kannada & Nandagudi, Bangalore District & Perbbāṇa Muttarasa \\
\hline 17 & eighth century & Telugu & Korrapāạu, Cuddapah District & $\begin{array}{c}\text { Perbāṇādhirāja } \\
\text { (Perbāṇa-adhirāja) }\end{array}$ \\
\hline 18 & ninth century & Tamil & Kīlputtūr, Chingleput District & Perumpāṇan \\
\hline
\end{tabular}

All the epigraphic data presented above show that the Telugu Cōlas as well as the Bānas were present in Anantapur, Cuddapah, and Kurnool Districts at least from the seventh or eighth century, if not earlier. If Cōlas could migrate to this region from the Tamil country, so could the Bānas to the same region as well as southern Karnataka.

This means that ca. first century BCE the original home of the Bạnas, known as Pānar then, was in the northern part of the Tamil country. Between then and the fourth century CE, when Kadamba king Mayūravarman levied tribute on the Brhadbānas, the Bānas seemed to have migrated to the region north of the Tamil country into Telugu and Kannada regions. In approximately the fifth century CE, when the Tâlagunda inscription was authored, they must have been called Perumpāṇar in Tamil, which became Perbāna or Perbbāna in Telugu and Kannada regions, respectively, and translated into Sanskrit as 
Bṛhadbāna. Later, under pressure from the Western Cālukyas, the Bānas moved south and returned to the region straddling the northern border of the Tamil country as well as the southern Telugu and Kannada regions.

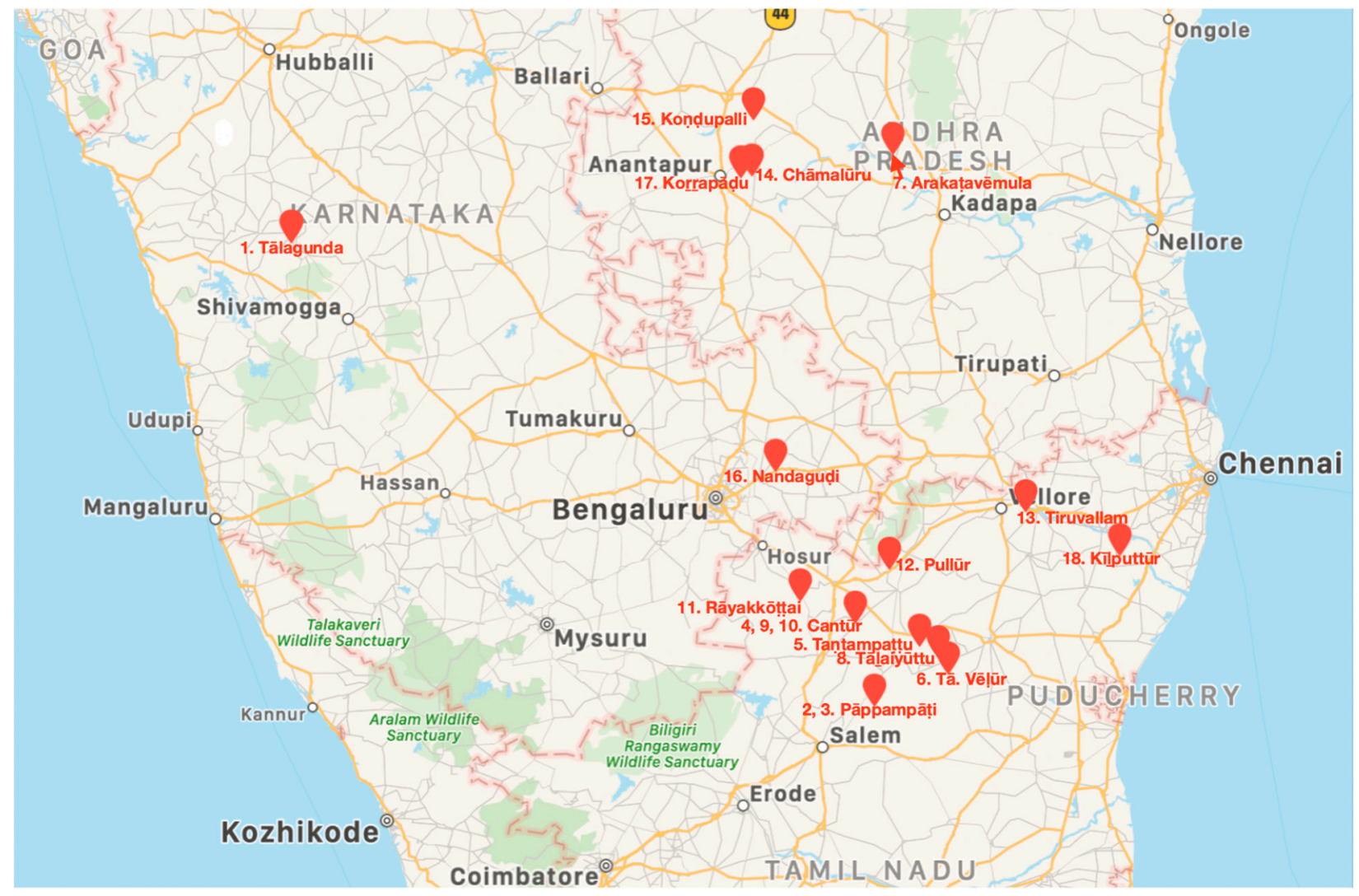

Figure 1. Locations of Inscriptions Mentioning the Bāṇas Shown in Table 1.

\subsection{Linguistic Variation from Pānar to Bāna}

The reasons for considering Sanskrit Bṛhadbāṇa as a borrowal from Tamil Perumpāṇar are discussed below.

The use of Peru- in combination with the name of a dynasty or profession as a title or name to denote recognition of excellence is an indigenous Tamil tradition. Examples include Peruñcēral (Patirrruppattu 8th Patikam, line 10), Peruñcōlan (Patirrruppattu 9th Patikam, line 6), Peruvaluti (The Tamil Varalatru Kazhagam 1967, p. 22), Perumuttaraiyan (Nālatịāar 200.1), and Perumpānan (Kalittokai 96.35). In contrast, the Sanskrit dynastic title, Bṛhadbāna is very unusual. The only other known dynastic title beginning in Bṛhat or Bṛhad, Bṛhatphālāyana, is not a dynastic title at all. In fact, in the case of Bṛhatphālāyanas and Sālankāyanas, according to Gopalachari (1941, p. 151), the scholars have simply used the gotra names in the absence of dynastic names. (Gopalachari 1941, p. 151, n.1). Moreover, it is only in the Tâlagunda inscription we find the occurrence of Bṛhadbāna. Everywhere else in non-Tamil inscriptions, the members of the dynasty are called with names beginning in Bānaa-, Perbbāṇa, Perbāna, and Vānaa-. In other words, we do not find Bṛhadbāna anywhere else. However, in Tamil, we find many instances of Perumpānaraicar, and Perumpannan. This leads one to infer that the author of the Tālagunda inscription was simply translating the name Perumpānan into Sanskrit. One of the features of Dravidian languages is that voiceless obstruents become voiced in post-nasal positions (Krishnamurti 2003, pp. 144-45). In Tamil, - $p$ - following nasal $-m$-is pronounced as $-b$-, but it is still written in Tamil with - $p$ - due to Tamil orthography. This means what is written as Perumpannan in Tamil is pronounced as Perumbānan. The author of the Tâlagunda inscription has translated the first component of this name, Tamil Perum-, as Brhad- in Sanskrit and 
rendered the second part as $-b \bar{a} n a$. This suggests that the original form of the dynastic name should have been Pạnan, which was later re-analyzed as Bāna.

It is also possible that in the Kannada and Telugu areas 'Panna-' was being pronounced as 'Bāna' due to $p-/ b$ - variations in word-initial positions such as in Tamil poykai 'natural spring or pond', Kannada bugge, and Telugu bugga (DEDR 4533) independent of the postnasal pronunciation of - $p$ - in Perumpānan (Krishnamurti 2003, pp. 130-31). Another such example is Tamil pommai 'puppet, doll, effigy' (DEDR 4530), Kannada bombe, and Telugu bomma. The Periyapurānam mentions two Śaiva devotees from the bardic community of Pānar. One was from the Pāntịya country and known as Pānanāār Pattiranāro where Pānanāa $\mathbf{r}^{37}$ is an epithet indicating that he is a respected person of the bardic community and Pattiran (<Sanskrit Bhadra) is his given name. The other one was Tirunilakanta Yālppānar from the Cōla country. ${ }^{38}$ For details regarding their stories, see Palaniappan (2016, pp. 316-22). The Periyapurānam was authored during the rule of Cōla Kulottunga II, who reigned from 1133-50 CE. The name Pānanāār Pattiran̄ār has been Sanskritized as Bānabhadra in Sānskrit works possibly due to the influence of Kannada or Telugu. A Kannada inscription from Ablūr in Karnataka mentions a Śaiva devotee by the name Bānan (Epigraphia Indica, vol. 5, 246). The editor of the inscription identifies Bānan with Bạnabhadra since the inscription also mentions Malayêśvara, presumably referring to the saint-king, Ceramān Perumāl, who interacted with the bardic devotee from Madurai (Epigraphia Indica, vol. 5, 254-55, n5). If this inscriptional Bānan represented one of the two bardic devotees, since the inscription is dated ca. $1101 \mathrm{CE}$, the inscription must reflect knowledge about that devotee on the part of the Kannada Śaiva tradition before $1101 \mathrm{CE}$ i.e., anterior to the Periyapurānam. ${ }^{39}$

The Sanskritized name Bānabhadra could also result from hypercorrection changing Pāna- to Bāna-. Harikesanallur Muthiah Bhagavatar, a well-known composer of Carnatic music songs and erstwhile palace musician of Mysore, has used the name Bānabhadra in a Sanskrit composition beginning in "pāñcavaktram āśraye'ham" in which Śiva is praised as one who is pleased with the music of Bānabhadra (Subramanian 1946, p. 313) ${ }^{40}$ In his biographical dictionary of Carnatic composers and musicians, Rajagopalan (1992, p. 59), refers to the Pānar devotee Pattiran as Bāṇabhadra. Elaine Fisher, in her summary of the story of the same Pānar devotee, calls him Bānabhadra too (Fisher 2017, p. 199). Thus, it is possible for Tamil Pānar > Bāna also with word-initial $p$ - changing to $b$ -

An extreme form of such hypercorrection is seen in the following excerpt from the book Mirror of Tamil and Sanskrit describing the content of a twelfth-century inscription in the Tiruvitaimarutūr temple (Nagaswamy (2012, pp. 373-74)). The inscription discusses the order by Cōla Kulottunga $\mathrm{II}^{41}$ to appoint a Pānan to sing before the deity, appoint other Pānar, and train two classes of temple women to sing.

A new service was started in the temple of Thiruvidaimarudūr creating an enactment for singing the Thirup-padiayams [sic] and also arranging for the dancing girls of the temple to sing in the 9th year of Vikramachola, the son of

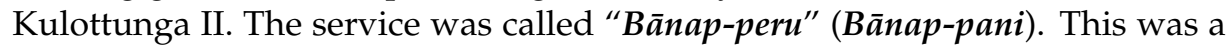
royal appointment issued by Vikkramachola [sic] and a certain Irumudi Cholan alias Acancala Peraraiayan [sic] was appointed to do the service...The record states that he was to sing in the presence of God of the Thiruvidaimarudūr temple and direct other Bānas for arranging the Dancing girls to sing (Thiruvidai marudurudaiyārukku—pādavum, ikkoyil Taliyilārai pāduvikkavum ikkoyil Devaradiyārai pāduvikkavum Bānapperāka). The Bānas were great singers from the Sangam age and we find the Bānas, Yālpāna was a close friend of Jnāna-sambandar and again we find the Bānas were appointed in the Great temple of Thanjavaur [sic]. According to this inscription the service should be added to the temple service and the Bāna should be paid one kalam of paddy per day to the Perariayan [sic] for singing. He should be allotted one residence as Bānak-kudiyiruppu as before ... It is interesting to note that the singing service is called Bānapperu. 
In the above excerpt, except for Yālpāna, all other instances of original Pāna- have been hypercorrected to Bāna!

Thus, whether due to the influence of post-nasal voicing of - $p$ - in Perumpānan or voicing of word-initial $p$ - in Kannada and Telugu or due to hypercorrection, Tamil Pānan changed into Bāna- in Kannada, Telugu, and Sanskrit.

Finally, there seems to be a difference between early literary sources and inscriptions when it comes to rendering Bāna in Tamil. As seen in inscription 10 in Table 1, Bāṇa is only rarely rendered in Tamil as Pān. . However, early Tamil literature has consistently rendered Bāna as Vānan. There is an instance in the Maturaik Kāñci, where the name Vānan seems to refer to Bāna, the Asura, in the context of referring to his fabulous wealth as given below.

tenpula marunkin vințu niraiya

vāṇan vaitta viluniti perinnum (Maturaik Käñ̃ci 202-03)

even if (you) obtain the excellent wealth, which Bāna, the Asura, stored so that it filled the mountains in the southern region

We should note that the Cilappatikāram refers more explicitly to the same Bānāsura as Vānan and not as Pānañ as given below.

vānan pēerūr marukițai națantu

nīl nilam alantōn àtiya kuțamum (Cilappatikāram 6.54-55)

the pot dance performed by the one who measured the vast world

having walked along the street of the city of Bāna

The Manimēkalai describes the dance of Kṛ̣na's son Pratyumna on the streets of Bāna's city in words reminiscent of the words of the Cilappatikäram above.

vāṇan pērūr marukițait tōñri

nīl nilam alantōn makan mun ātitya

pẹtik kōlattup pèțu ... (Maṇimēkalai 3.123-25)

the transgender dance, which the son of the one who measured the vast world

having appeared on the street of the city of Bāna as a transgender person and danced

Clearly, the Tamil texts that had been composed in the sixth century CE or earlier consistently refer to the name Bāna as Vānan. When the Cankam poems were authored, if they had to refer to a Bāna chief, since Tamil did not have the phoneme ' $b$ ', they would have referred to him as 'Vānañ' and not as 'Pānann'. Since Akanānnūru 113, 226, 325, and 386 refer to chief 'Pānan', the original pronunciation of the chief's name should have been 'Pānan' and there was no association of these chiefs with Bāna, the Asura.

Even Peruntokai 1190, a medieval poem of ca. twelfth century, maintains the distinction between Bāna, the chief, and Pānann, the bard, as given below (Irākavaiyañkār 1935-36, p. 272).

ulaikku uriya panțam uvantu irakkac cenzrāal

kolaikku uriya vēlam koṭuttān一_kalaikku uriya

vānar kōn ārai makatēcanukku intap

pānañōtu ennna pakai

When I went to solicit provisions meant for cooking

he gave a male elephant meant for killing.

For Makatēcan of Ārakalūr, the chief of the Bānas, renowned for art, what is the enmity towards this Pānan, the bard? 
The original name of the Pānan chiefs changed to 'Bāna', when their territory shifted outside the Tamil region. When contemporary dynasties were Sanskritizing and inventing Purānic pedigrees, the Bānas connected their lineage to Bāna, the Asura. Later when they moved south under pressure from the Western Cālukyas, 'Bāṇa' became 'Vāna' following long-established linguistic and philological patterns. Thus, we have the following sound variation in the name of this dynasty:

Pānạn > Bāṇa > Vāṇan

\subsection{Summary of the Arguments for the Origin of the Bānas from the Tamil Pānar}

In the discussion so far, the following have been established.

\subsubsection{The Bards Were Also Warriors}

The usages, porāap porunan and atu porunan, show that Tamil bards and warriors were from the same community but differed in their functions. The description of arms like the concert drum (mulavuttōl) in the case of the bards just like in the case of warriors and Pānan with such arms killing a fighter in Akanān $\underline{u} \underline{r} u 386$ establishes the bards to be from the same warrior community. Moreover, Kuruntokai 328 also establishes the Pānar as warriors/chiefs. Additionally, Akanān̄ūru 189 employs the word mallar (warriors) to refer to bards.

\subsubsection{A Section of Pāṇar Being Rulers}

There was a country the Pānar possessed that was called the good land of Pānan (Akanānuūru 113 and 325) or Pānāṭu (Akanānnūru 155). It has been shown using Tamil philology that Pạnan was the chief of his land.

\subsubsection{Bānas Originating from Tamil Pānar}

The link between the Pānar, the bards, and the Bānas is provided by the use of Bṛhadbāna in the Tạlagunda inscription (fifth century CE), the first inscription dealing with the Bāṇas and the use of Perumpān and Perumpanān in Cankam literature. The use of 'Bṛhadbāna' is seen a few centuries later than the use of 'Perumpāṇ' (Narrinai 40.3 and Maturaik Kãñ i 342). Thus, while the direction of borrowing could work both ways between Bṛhat- and Perum-, the Tamil attestation of Perumpān clearly precedes Bṛhadbāṇa giving primacy to Perum- > Bṛhat- in this case.

Can one argue that the only evidence for the presence of Bānas at the time of Cānkam literature (because no written evidence of Kannada or Telugu existed that early) is given by the Tamilized name Pāṇan mentioned above (<Bāṇa) and associated Pānātu? This is ruled out because of Pāṇātu translated into Pāṇarāṣtra is attested in the Lokavibhāga. If the original name of the Bāna dynasty indeed began with B-, since the Bānas had continued to exist as the Bānas (as shown by the Tạlagunda inscription), Sanskrit Lokavibhāga of the sixth century would have presented their land as Bāṇarāștra. It did not. However, the Cankam period usage of the name Pānātu had continued up to the time of the Pāraiyañpattu inscription (sixth century $\mathrm{CE}$ ).

Considering all this, we can conclude that a section of the Tamil bards, Pānar, became rulers of a territory in the northern part of the Tamil country. They migrated to Kannada and Telugu lands and came to be known as the Bānas. Later, they moved back into the Tamil country and the region under their control was known as Perumpānappāti. Later, they also claimed to be descendents of Mahābali, the Asura. In the next part, we shall explore the motivations for such a claim of theirs.

\section{Sanskritization and Sovereignty of the Pānar/Bānas}

\subsection{Tamil Idea of Kingship}

Tamilakam, the name for the Tamil country, was ruled by a confederacy of three kingdoms of Cēra, Cōla, and Pāntịya for a long time. The kings belonging to the three dynasties were called the mūvēntar (three kings) or mutiyutai vēntar müvar (three kings with crowns). In addition to these three, there were also several minor kings or chiefs called 
kurunila mannar (kings of small territories), who often allied with one or the other three kings. Indeed, one dynasty of these chiefs is mentioned in the second rock edict of Aśoka as Satiyaputō, known in Tamil as Atiyamān or Atiyañ. The Brāhmī inscription at Jambai mentions Satiyaputō Atiyan Nețuān Añci, a member of this dynasty (Mahadevan 2003, pp. 399, 588-90). Another dynasty of chiefs was the Pānar, whose members had survived at least from the first century BCE for more than 11 centuries. They were also known as the Bānas. ${ }^{42}$

The early Tamil concept of kingship is expressed in the following Classical Tamil poem (Puranāñūru 186) translated by Hart and Heifetz (1999, p. 119).

Rice is not the life of the world nor is water the life!

The king is the life of this world with its wide expanses!

And so it is incumbent upon a king who maintains an army

wielding many spears to know of himself: "I am this world's life!"

Thus, the Tamil view of kingship focused on the king's life which is the life of his country. In the Cankam society, the legitimacy for the king's sovereignty did not depend on any divine intervention or grace or descent from Indo-Aryan gods. It depended on his ability to sustain and protect his subjects. This often involved warfare in the heroic age in which they lived. Their success in warfare and their ability to protect the subjects earned for them and their ancestors lasting fame.

\subsection{Sanskritization}

The Cankam literature also shows the beginnings of an influx of Indo-Aryan myths that were used by poets to praise the kings. The Cōla kings were praised as descendants of Śibi, who saved a pigeon that took refuge with him, by offering his own flesh to the hawk that was pursuing the pigeon. ${ }^{43}$ Another poet praised the chief Irunkō alias Irunkōvēl as the chief among chiefs who ruled the City of Tuvarai (Dvāraka?) for 49 generations with their progenitor having been born in a pot or sacrificial pit of a sage in the northern region. There is really no evidence for any ruler basing his legitimacy on such stories, in spite of the poets using them. This will, however, change as Sanskritization increased over the centuries.

By the eighth century CE, South Indian kings were buttressing their claims of royal legitimacy with descent from gods like Viṣnu, Brahmā, Sun, Moon, or Vedic sages. ${ }^{44}$ For instance, we saw earlier that the Telugu Cōlas claimed to belong to the lineage of the Sun, and the Pantịyas claimed to belong to the lineage of the Moon (The Tamil Varalatru Kazhagam 1967, p. 33). The Rāyakkōtțai plates of Pallava Skandaśisyavarman of the eighth century claim the Pallavas to belong to the lineage of Viṣnu, Brahmā, Angiras, Bṛhaspati, Śamyyu, Bharadvāja, and Droṇa (Epigraphia Indica, vol. 5, p. 52). The Udayēndiram plates of Prithivipati II issued in the early tenth century CE include a Cōla genealogy including Viṣnu, Brahmā, Kaśyapa, Sun, Rudrajit, Candrajit, Śibi, Kōkkiḷı, Cōlala, and Karikāla. ${ }^{45}$

The Tamil Buddhist epic, the Manimékalai, mentions that the queen of the Tamil Cōla king was the daughter of a descendant of Māvali (Mahābali). Although it does not explicitly mention the name Pāna or Vāna, given the absence of any other ruling dynasty claiming to belong to the lineage of Mahäbali, it is obvious that it is the earliest mention of the Mahabali Bānas. The earliest inscriptional mention of Mahābalivānarājar occurs in the Rāyakkōtțai plates of Pallava Skandaśisyavarman of the eighth century CE, we noted earlier. Thus, the Bānas alone claimed to be descendants of Asuras or demons.

The Bāna dynasty's choice of Bali as the progenitor of the lineage seems to have been based on the fact that the Sanskrit mythology had named Bali's son as Bāna or Bānāasura.

\subsection{Bali Mythology in Bāna Inscriptions}

In an eighth-century inscription in Tiruvallam in North Arcot District, ${ }^{46}$ the expression "sakala-jagat-tray-ābhivandita-sur-āsur-ādhīśa-Parameśvara-pratihārī-krta-Mahābali- 
kulotbhava-Śrīmāvalivānarāyar" is found, which is translated by E. Hultzsch as "the glorious Māvalivānarāya, -born from the family of Mahābali, who had been made door-keeper by the lord of gods and demons, Paramēśvara (Śiva), who is worshipped in all three worlds." ${ }^{\prime 7}$ However, Venkayya says the following (Epigraphia Indica, vol. 11, p. 232, n. 4) regarding an alternate interpretation:

The expression sakala-jagat-tray-ābhivandita-sur-āsur-ādhīśa-Parameśvara-pratihārīkrta-Mahäbali-kulodbhava is translated by Mr. [Lewis] Rice, on the strength of some Kanarese tradition, "born of the family of Mahābali, who had made Paramēśvara, lord of gods and demons worshipped in all the three worlds, (his) door-keeper;" Ep. Car. Vol. X. p. ii, Note 5.

While being a doorkeeper may not be attractive for a dynasty trying to showcase its legitimacy of sovereignty, having Śiva as a doorkeeper would certainly add to its prestige. A more detailed genealogy of the Bānas is provided in the Udayēndiram Plates of the Bāna king Vijayabāhu Vikramāditya III ${ }^{48}$ of the tenth century.

(Verse 1.) May that Siva promote your well-being, whose true nature even the Vèda cannot fully reveal, from whom the creation, the preservation, and the destruction of all the worlds proceed, on whom the devotees meditate, (and) whose two feet are tinged with the collections of red rays of the rows of jewels in the diadems of the crowds of the chiefs of the gods who in person bow down before him!

(V. 2) May that Nārāyana, whose body ever rests on the lord of serpents, (and) whose two feet are worshipped by crowds of gods, guard you! He, whom the gods and Asuras, desirous of churning the matchless sea of milk, discarding the Mandara laid hold of, as it were, to obtain a second time the nectar of immortality, (and) who then shone, even more than ordinarily, as if he were the Añjana mountain!

(V. 3.) There was the regent of the Asuras, named Bali, whose sole delight it was to engage in acts of violence towards the gods, while his one vow was, to worship the two feet of Śiva. He, after having presented as an excellent sacrifice a respectful offering to the primeval god, the enemy of the Daityas, with great joy (also) gave to him who bore the form of a dwarf the earth with its islands and with all things movable and immovable.

(V. 4.) From him sprang a mighty son, a treasure-house of good qualities, towards whom was ever increasing the great pure favour of Śambhu on whose head are the lines of the lustre of a portion of the moon, -Bāna, the foe of the gods, who with his sword struck down the forces of his enemies.

(V. 5.) As the cool-rayed moon rose from the sea of milk, so was born in his lineage Bānādhirāja, who, possessed of never-failing might, with his sharp sword cut up his enemies in battle.

(V. 6.) When Bānāāhirāja and many other Bāna princes had passed away, there was born in this (lineage), not the least (of its members), Jayanandivarman, the fortune of victory incarnate, and an abode of fortune.

(V.7.) This unique hero of great might ruled the land to the west of the Andhra country, like a bride sprung from a noble family unshared by others, having his feet tinged by the crest-jewels of princes.

(V.15.) To him was born a son Vijayabāhu, named Vikramāditya a unique light of the Bāna family, who has followed the path of prudent conduct, before whom the assemblage of opponents has bowed down, (and) who has Krishṇarāja for his friend. Eminently prosperous (he is, and) free from evil and distress. 
(Line 45.) This (prince), the dust of whose feet is tinged with the lustre of the jewels on the edges of the diadems of all princes without exception, and whose two arms are filled with ample fame, gained in victories over the multitude of arms of the adherents of many different hostile princes, after pouring out a stream of water from the beautiful golden jar, held by the palms of his hands the bracelets on which are thickly covered with various bright jewels, - (has given) to the excellent twice-born, dwelling at Udayēndumangala, who delight in, what is their proper duty, the knowledge of the truth of all the Vēdas and Vēdāngas and philosophy, (and) are eager to impart the knowledge of things which is stored up in their minds, ...

Here, we can see the explicit connection between Bāna, the Asura, and the Bāna chiefs. The aim of the plates was to issue a grant to the twice-born or Brahmins. What is interesting in this genealogical description of the Bāna king is that verse 3 notes how Bali gave the entire earth with great joy to the enemy of Asuras, Viṣnu, who took the form of a dwarf.

The seemingly strange thing about the choice of Bali as the progenitor of the lineage is that according to Sanskrit mythology, his grandfather was Prahlāda (Taylor 2021, p. 141). The Bānas' choice of Bali seems strange also because, the stories of Vāmana incarnation of Viṣnu in the extant Sanskrit texts mention that Bali lost his sovereignty of the world and was forced to live in Pātāla. ${ }^{49}$ Here is how Bali's story is presented in the Mahāabhärata (12.326.74-76).

The great Asura Bali, the powerful son of Virocana, will arise and cause Indra to fall from his kingdom. When the triple world has been stolen by him despite the opposition of the husband of Śacī, I will take birth as the twelfth son of Aditi and Kaśyapa. Then I shall restore the kingdom to Indra, of infinite glory. I shall return the Devas to their positions, O Nārada, and Bali I shall cause to dwell in the region of Pātāla.

(Hospital 1984, pp. 25-26)

Here, Bali is presented as stealing what was not his. However, over time, his portrayal in Sanskrit texts changes. Hospital (1984, pp. 262-63) says:

We can see Bali bearing different kinds of relationships to Indian attempts to conceptualize what is significant, valuable and real. In the earlier phases of the Epic-Purānic [sic] texts, Bali represents forces inimical to a central idealized reality of the universe., that of dharma (virtue, righteousness, and order). Thus Viṣnu, often seen as upholding dharma, is portrayed in his Dwarf avațāra as overcoming this disorderly and disturbing force.

But gradually, the focus shifts, and in the period of the middle and later Purānas the total corpus of Bali presents something of a debate or tension between different foci of significance-dharma, bhakti, and prosperity. In Bali there is an exploration of the relation between these features, of which the total effect is to suggest that although Bali may be good, and a great devotee, that does not necessarily mean that his kingly role is legitimate. The fact that his kingdom is eminently prosperous may even be seen as problematic. But from another viewpoint within the same arena of debate, Bali can be shown as the true devotee who has learned not to be attached to anything. Bali lost his kingdom but found his Lord.

Some Sanskrit texts that have Bali losing his sovereignty also have stories of Bāna, the son of Bali, ruling as a king. For instance, the Harivamśa makes it clear that Bali was still in Pātāla, when Bāṇa was ruling as a king (Broadbeck 2019, p. 312). For a group trying to establish its legitimacy of sovereignty, to choose a king who lost his sovereignty would be a strange choice indeed. There must be some other reason outside the Sanskrit world. What could it have been? 
Unfortunately, Hospital (1984) did not address the question of the Bāna chiefs claiming Bali to be their progenitor. We do not know the relative dating of all the texts vis à vis the Bānas' claim to belong to the lineage from Bali.

\subsection{Why Choose Bali as the Progenitor of the Dynasty?}

Let us look at the possible reasons as to why the Bānas could have chosen Bali as their progenitor. It would make sense if there was a different tradition of stories in South India that had a different outcome for Bali's encounter with Vāmana. After all, the earliest mention of Mahābali connecting him to a dynasty occurs in the sixth-century text, the Maṇimēkalai mentioned earlier (Richman 1988, p. 161).

The Vāmana avatāra is mentioned in Tirukkural 610 dated 450-500 CE (Zvelebil 1975, p. 124). Cilappatikāram 6.55 of ca. 450 CE (Zvelebil 1975, p. 114) calls Viṣnu as nīl nilam alantōn (one who measured the extended world). Later Cilappatikāram 17.34.2 mentions Viṣnu covering all the three worlds in two steps and Cilappatikāram 17.35.1-2 mentions Viṣnu covering all the three worlds in under two steps. There is no mention of Bali here.

The Cilappatikāram, however, has stories connected to Bāna, the son of Bali, which are not found in the Sanskrit texts. The Cilappatikāram mentions that Mātavi, the dancer, with whom the hero Kōvalan fell in love, knew how to perform well the following 11 dances. $^{50}$

Koțkoțti-dance of Śiva clapping his hands at the time he burnt down the triple cities

Pāṇtarañkam-dance by (Śiva in the form of) Bhāratī who applied ash all over the body at the time he destroyed the triple cities

Alliyam-dance by Krṣna when he broke the tusk and killed the elephant sent by Kaṃsa to kill Kṛ̣ṇa

Mal—dance by Viṣnu when he defeated the demon (Bāṇāsura) in wrestling ${ }^{51}$

Tuti-dance by Murukan with the tuti drum when he killed the demon standing as a Mango tree in the sea

Kutai-dance by Murukan with an umbrella/parasol when he defeated the demons

Kuṭam-dance by Kṛ̣ṇa with pots on the streets of the city of Bāṇa (Bāṇāsura) when Bāṇa had imprisoned Aniruddha, the grandson of Kṛ̣na

Pẹtu-dance by Kāma, who took the form of a transgender person (in Bānāsura's city)

Marakkāl—dance by Durgā when she wore wooden legs to defeat the demons

Pāvai-dance by Lakṣmī in the form of beautiful Kollippāvai at the time she defeated the demons

Kaṭaiyam-dance by Indrāṇi at the northern gate in the city (of Bāṇāsura)

In the above list of 11 dances, four involve stories related to Bānāsura, Bali's son. Cilappatikāram 17.35.3 also mentions the destruction of the fort of the City of Cō (Sōnitapura) of Bāna by Viṣnu-Krṣna. This shows the popularity of stories connected with Bāna in the Tamil country in the fifth century CE. However, these stories are not found in any Sanskrit texts such as the Harivamiśa and Viṣnu Purāna (Broadbeck (2019, pp. 311-43); Taylor (2021, pp. 424-28). Discussing the history of the story of the Cilappatikāram, Parthasarathy (1993, p. 318) says:

It is generally accepted that the Cilappatikāram existed long before it was put down in writing. Scholars are of the opinion that the epic, with the rest of early Tamil literature, must have had a long oral existence before it acquired its present form. For generations, bards ( $p \bar{a} n \underline{n} a \underline{n} s$ ) have recited or sung the story of Kōvalan throughout the Tamil country, embellishing it with myths. It was this story from 
the oral tradition that was at some point transcribed by a learned poet (pulavan). Thereafter, both the oral and written versions freely circulated, each drawing upon the other. One such written version that has come down to us from the distant past is attributed by tradition to Ilankinō Ațikal, a prince of the Cēral royal family and Jaina monk.

These, along with the Kannada tradition of Siva being the doorkeeper of Bāna according to Lewis Rice mentioned earlier, suggest the possibility that there could have been stories related to Bali too, in which he might not have lost his sovereignty. The present Kerala tradition of Mahābali and Ōnam, which considers Bali to have been a good king, who returns to Kerala once a year, might contain traces of an early tradition regarding Bali in the Tamil country, which had not been picked up by early written literature.

Beyond the question of whether there was a tradition of Bali in South India different from what is found in the Sanskrit texts, the story of Bali might have had a special resonance for those familiar with the Tamil bardic culture and especially participants in that culture, the bards.

\subsection{Pān Katan of the Bardic Culture}

One of the Cankam era Tamil chiefs was Pāri, who ruled the territory which included the hill called Parampu Malai. Pāri was one of the seven famous Tamil chieftains of the Classical Tamil period known for their philanthropy. The three Tamil kings wanted to marry the daughters of Pāri. However, for some reason Pāri refused and the angry kings formed an alliance and laid siege to his hill. However, it was of no use. The hill was self-sufficient in all respects and Pāri did not surrender. The siege went on for a long time. Pari's close friend was a poet called Kapilar. Kapilar wanted to tell the three kings their efforts were useless. One day he went down to the kings and told them:

maram torum pinitta kalịrrininir āyinum

pulam torum pinitta têrinirir āyinum

tālil kollạilir vāịlil tāralan

yān arikuvan atu kolllum ārē

cukir puri narampin cīriyāl panni

viraiyoli kūntal num viraliyar pin vara

àținir pātinin celin̄e

nātum kuñrum oruñku ìyummēe (Puranān̄ūru 109.11-18)

Though you have tied your elephants to every tree there,

though your chariots are spread all over the fields,

you will not defeat him through your efforts!

He will not give in to your swords.

But I do know how you can obtain his possessions!

If you, [as Pānar,] would only play on a small lute with its polished twisted strings

while your [queens follow you as] Viralis with their rich fragrant hair,

and you come dancing and singing,

he will give as gift his country as well as his hill.

Although Kapilar's advice was meant to dissuade the kings from continuing the hostilities, according to Tamil tradition, the three kings took up the idea of passing off as bards seriously and did succeed in capturing the chiefdom of Pāri, and also killed him ${ }^{52}$. What this story highlights is the concept of pān katan 'the duty or obligation towards the 
bards or minstrels' held dear by the Tamil kings during the heroic age or the bardic age of the Tamils. According to Kailasapathy (1968, p. 57),

... the word katan is used in the particular sense of duty or responsibility. It is in this sense that a responsibility for the bards is prescribed for the kings. It may not have been as rigid as legal enactments. But the conduct of the heroic society was itself bound by a code of honour and the obligation to adhere to it was almost absolute...

When one compares the attitude of Pāri, who was willing to lose his sovereignty and even life for upholding his duty towards the bards, with that of Bali, who was willing to lose his sovereignty for honoring his word to give three 'steps' of land to the Brahmin Vāmana, one can see a willingness to carry through one's philanthropic commitment to another person in both. In the case of Prahlāda, Bali's grandfather, he was known for his steadfastness in his religious devotion, but not a philanthropic commitment to somebody else. That Bali's philanthropic commitment was valued by the Bānas can be seen in the Udayēndiram Plates' mention of Bali giving with joy the whole earth to his enemy, Viṣnu in the form of a dwarf. Considering that it was most probably due to the concept of $p \bar{a}$. katan that the Pānar/Bānas obtained their territory to begin with, it is probably because of Bali's philanthropic commitment that the Pānar/Bānas chose to have Bali as the progenitor of their lineage instead of Prahlāda.

Moreover, even towards the later part of the Cankam period, when chiefs known for philanthropy like Pāri had been long gone, the rulers treated alike the bards, poets, and the Brahmins with regard to philanthropy. For example, according to Cirupāna $\bar{a} \underline{r} \underline{r} u p p a t a i$ 203-206, the entrance to chief Nalliyakkōtann's well-guarded palace was always open to bards, poets, and Brahmins. So, the bards, who had earlier received villages and territories from rulers could probably relate to the Brahmin Vāmana receiving land from Bali. Given the parallelism between the importance of the Brahmin to the Indo-Aryan king and the importance of the bard to the Tamil king of the bardic age as laid out earlier by Saskia Kersenboom-Story, the Bānas could probably appreciate Bali's solicitous attitude towards Vāmana.

As Sanskritization increased over the post-Cankam period, and other rulers invented Purānnic pedigrees, the Pānar / Bānas did not resort to an origin from a Vedic sage or Sun or Moon but seemed to have settled on Bali as their progenitor. In this, while the lineage of Bāna, the Asura, might have been chosen because of the name Bāna, the choice of Bali as the progenitor was probably due to his philanthropic nature similar to the pān katan of early Tamil kings.

After all, if anybody tried to belittle their origin, they could claim that it was Bali who magnanimously gave Viṣnu-Vāmana his land just like earlier Tamil rulers had given the bards their territory. It also happened that Bali's son was their namesake.

\section{Conclusions}

The Bānas were an important minor dynasty of rulers in South India. They survived for more than a millennium and married into royal dynasties like the Cōlas. The Bānas were referred to as Bṛhadbānas in the Tālagunda inscription. Many historians have noted its semantic similarity with the Tamil term Perumpānan, a term to denote excellent bards. However, no scholar has analyzed how this similarity has come about. In this essay, I first looked at the role of bards in early Tamil society and any socio-political changes that might have happened over time. Then, I looked at the epigraphic records of the Bānas from a wide area of South India as well as literary texts in Tamil from first century BCE up to the twelfth century $\mathrm{CE}$. I hoped to arrive at a reasonable conclusion regarding the origin of the Bāna dynasty. However, that is only half the story. The Bānas have been unique in Indian history in Sanskritizing their origin story in which they claimed as their progenitor Bali, the Purānic Asura, who lost his sovereignty and was exiled to the netherworld by Viṣnu-Vāmana. I hoped to explore the possible motivations behind this claim too. Here are the findings. 
The early Tamil bards had an important role in the society and especially with respect to kings and chiefs. The bards were known by different names depending on what they performed. They were considered to have ancient wisdom and believed to bring auspiciousness and prosperity. By their oral poetry and performance of music and dance, they disseminated the valorous deeds of the rulers and their ancestors contributing to their lasting fame. Consequently, the bards were treated with respect by the kings and chiefs, who offered them gifts like elephant and gold ornaments. However, more importantly, they also gave them land which could range from small villages to large territories. This much has been known already.

What has not been widely known till now is the fact that there was no difference between the bards and warriors in terms of social origins. They were all from the same community. Sometimes they were even called by the same name such as the Porunar and Mallar. Given these facts, it is easy to imagine how a bard, who has received a large territory as a gift, might choose to become a ruler himself. This has happened very early in the Tamil history with a ruler or rulers mentioned in Cankam literature as Pānan. Tamil scholar Auvai Turaicāmip Pillai was the first to suggest this ruler's lineage as the origin for the Bānas. While some Tamil scholars accepted this finding, historians have been reluctant to do so. These historians looked on the Bānas as non-Tamils with an origin in the Telugu-Kannada areas.

A careful analysis of the literary and epigraphic data shows that the Tamil Pānar dynasty got its start in the northern part of the Tamil country as early as the first century BCE. Then, for some political reasons such as possible Kalabhra incursions into their region, they moved further north into Telugu and Kannada areas. In this, they were similar to the Cōlas, a branch of whom established themselves as the Rēnāṇ̣u Cōlas or Telugu Cōlas at the same time.

Concomitant with the move into non-Tamil areas, there was a linguistic variation introduced into their name, which changed from Pānar to Bāna. Later, when they came under pressure from the Western Cālukyas, the Bānas moved back into the northern part of the Tamil area known as Perumpannappāti. Their move back into the Tamil area introduced another linguistic variation in their name from Bāṇa to Vānar. The linguistic history of their name can be shown as Pānar > Bāna > Vānar.

Their move into non-Tamil areas was also the time when their contemporary neighboring dynasties were Sanskritizing their origins and claiming themselves to be descendants of Vedic sages or gods, Sun and Moon, with a view to claiming to be paramount overlords of the world as discussed by Ali (2000, p. 185). May be because their name happened to be Bāna at that time, the Bānas seemed to choose to link themselves to Puranic Bāna, the Asura. However, Bāna's father was Bali, whose father was Virocana, and whose father was the famous Prahlāda. Prahlāda's father was the notorious Hiranyakaśipu, who was killed by Viṣnu-Narasiṃha. Given this lineage, one would not expect the Bānas to claim Hiranyakaśipu to be their progenitor. Prahlāda was a devotee of Viṣnu and the Bānas might have been expected to choose him as their progenitor. They did not. Instead, they chose Bali, who lost his sovereignty and was exiled to the netherworld by Viṣnu-Vāmana.

Why did the Bānas choose Bali as their progenitor? The Tamil texts like the Cilappatikāram and the Manimēekalai as well as local traditions in Kannada-speaking areas point to differences in stories related to Bāna that seem to suggest that what we find in Sanskrit texts form only a subset valorized by the authors of those texts. This means that the local traditions involving Bali might possibly have presented a more positive view of him, which made him acceptable as a progenitor.

Alternately, if one considers the context in which Bali lost his sovereignty, there might be another reason for the choice by the Bānas. Viṣnu-Vāmana went to Bali as a Brahmin dwarf and asked for three strides of land. True to his philanthropic attitude, Bali agreed to that request. However, then Viṣnu-Vāmana grew into his cosmic form and took all the land Bali had. In effect, Bali lost his sovereignty to a deception perpetrated by Viṣnu. Having come from the Tamil Bardic tradition, the Bānas would have been familiar with the story of 
Pāri, who was committed to upholding the heroic age's code of pān katan, which required the ruler to protect and support the bards. However, Pari was treacherously deceived by the three Tamil kings who possibly disguised themselves as bards and took his kingdom and killed him. Originating in the bardic community, the Bannas might have valued the philanthropic attitude of Bali highly and disregarded his loss of sovereignty.

An important result of this research is the finding that the varna system did not apply to the early Tamil society. Palaniappan (2008, pp. 49-50) had indirectly shown that the four-fold varna system did not apply to the early Tamil society. We know that bards in early Tamil society fished ${ }^{53}$ and sold fish ${ }^{54}$ as well as made music. In other words, the same community would have done jobs that belonged to different varnas. This work shows that the early Tamil society was open enough for a bard to become a ruler of a territory and establish a dynasty that lasted more than a millennium.

Funding: This research received no external funding.

Acknowledgments: I gratefully acknowledge E. Annamalai for reviewing an earlier draft of this article and providing valuable comments. I also thank the two anonymous reviewers of an earlier version of this article for their helpful comments that have improved the article. I acknowledge the help by Robert Zydenbos and Caleb Simmons in clarifying some Kannada texts. I also acknowledge the help by S. Rajagopal and Michael Lockwood in getting some key epigraphic data. I thank N. Ramanathan for providing access to Harikesanallur L. Muthiah Bhagavatar's compositions. Any remaining errors are my own.

Conflicts of Interest: The author declares no conflict of interest.

\section{Notes}

1 From the Mahābhārata to the Bhāgavatapurāna, the story of Bali varies in its details. Bali, an Asura, had defeated the Devas and Indra and ruled the triple world as a king. When the Devas pleaded with Viṣnu to intervene, Viṣnu incarnated as Vāmana, a dwarf Brahmin. He went to Bali who was performing a sacrifice. At the sacrifice when Bali asked Vāmana what gift he wanted, Vamana requested that he be given land that could be measured in three steps. Bali agreed to the request. Immediately Vāmana grew into the giant cosmic form of Trivikrama and covered the triple world in two steps. There was no place for him to place his foot for the third step. Then, Bali asked Viṣnu-Vāmana to put his foot on Bali's own head. Viṣnu-Vāmana put his third step on Bali's head and sent him to Pātāla, the netherworld. Viṣnu-Vāmana restored Indra as the king of the Devas. For more details of the Bali story, see Hospital (1984).

2 Poruna, Kōtiyar Talaiva, and Ēlin Kilava are the vocative forms of Porunan, Kōtiyar Talaivan, and Ēlin Killavan, respectively.

3 In a Tanjavur temple inscription (South Indian Inscriptions, vol. 2, vol. 2, no. 66, p. 274), Maraikkātțuk Kaṇavatiyāña Tiruvelḷaraiccākkai was given a grant to sing for dance programs. His name can be translated as 'Maraikkāțtu Ganapati, who is the Cākkai Theater performer from the village of Tiruvelḷarai.' Evidently, he was a performer of Cākkaikkūttu, a dramatic art as well as a singer. The same inscription has two Pānar grantees with the title Cākkai.

4 See (Arunachalam 1977, pp. 27, 49; Hart and Heifetz 1999, p. 322). However, Zvelebil (1992, p. 29) considered the bards to be part of the elite strata of the Tamil society.

5 Using data from Tamil philology, epigraphy, Jainism, and Dravidian linguistics, Palaniappan (2008) showed there was no notion of untouchability during the Classical Tamil period. Using Tamil philology as well as epigraphy, Palaniappan (2016) showed that notwithstanding their portrayal as a low caste in hagiographic works, in real life, the Tamil Pānar enjoyed high status, performed in Sanskrit theater, sang in front of the deities in Brahmanic temples, and trained temple women to sing until the advent of the Vijayanagar rule in the Tamil country. Even during and after the Vijayanagara rule, the Tamil Pānar never became untouchables. Palaniappan (2016, p. 307) also noted, “Ludden (1996, p. 123) has presented demographic data from 1823 from the Tirunelvēli area that showed that the Pānar were one of several castes that formed the large non-untouchable Súdra category. Additionally, Thurston (1909, p. 29) has presented ethnographic information, according to which the Pānar employed Brahmins and Veḷālas as priests and could enter temples".

6 Unless otherwise stated, translations in this essay are mine.

7 Akanānūūu Manimițai Pavalam 226.

8 Perumpānappāti is mentioned in South Indian Inscriptions, vol. 3, no. 52, p. 112 as 'jayañkonțacolamanțalattu tiyākāparanavalanātțu perumpānappāți karaivali brāhmadeyam tiruvallattu tiruvallamuțaiyārkoyil' This can be translated as 'the temple of Tiruvallamutaiyār in the Brāhmadeyam of Tiruvallam along the riverbank in Perumpāṇappāṭi of Tiyākāparaṇavalanāṭu of Jayanikoṇtacōlamaṇtalam’.

9 For consulting Akanānūuru 113, 226, 155, 325, and 386, see the 1933 edition by Rākavaiyañkār and Irājakōpālāryan as well as the edition by Nāțtar and Pịllai. However, two corrections need to be made. In Akanān $\underline{u} \underline{r} u$ 113, my interpretation of elāap pānan is 
'non-music making Pāṇann' instead of 'Pāṇan ... who never shows his back in battle.' In Akanānnūru 226, as Turaicāmip Piḷlai states Kați came to fight against Pānan, who was in the Cōla court. Pānan did not accompany Kațit.

10 This occurs in the inscription as "pakkavādyar alakiyacōlatterintavalañkaivēlaikkāraril aiyāran antari ... I have differentiated between long $\overline{\mathrm{e}} / \overline{\mathrm{o}}$ from short $\mathrm{e} / \mathrm{o}$ while the inscription does not do so. The square brackets indicating indistinct letters as shown in the South Indian Inscriptions, vol. 2, no. 66 are not shown here for the sake of readability.

11 DEDR 77 aț $u$ means 'kill, destroy, conquer'. In fact, there is a specific grammatical term called Velippatai to refer to such usages where the intended meaning is made explicit.

12 Cōmacuntaran̄ār, the modern editor, following the fourteenth-century commentator Naccinārkkiniyar, explains it as ‘Porunar bards with tațāri drums who have arms like concert drums and who have the nature of opposition/disagreement due to education.' Cāminātaiyar in his Pattuppātṭu edition explains, "Having arms like concert drums' refers to their ability to oppose with physical strength rather than education." My translation above is based on possible meanings related to physical strength. In fact, according to the Tamil Lexicon, the possible meanings of muran are 1. Variance, opposition; perversity; 2 . Spite, hatred; 3. Fight, battle; 4. A mode of versification in which there is antithesis of words or ideas; 5 . Strength; 6. Greatness; 7 . Roughness; stubbornness; 8. Fierceness; 9. A flaw in rubies. It should be noted that tōl is often interpreted as 'shoulder' (Hart 2015, p. 387). It really means 'arm' as is clear from Kalittokai 109.13-15. The gift of flowers made of gold is a certain indication that the recipients were bards as in Puranān̄ūru 29.1-5 we saw earlier.

13 Many scholars interpret Pānan as an ally of Kați who fled without fighting in the court of the Cōla king. That is not accurate. It was Pānan, who was in the court of the Cōla king, the intended adversary of Kațti. Modern scholars like Nātțār and Piḷlai unnecessarily add a word ' $k \bar{u} t i$ ' meaning 'having joined' to "Pānanotu' to come up with the misinterpreted meaning. The nature of the verb 'poru' 'to fight' is that it is preceded by the adversary being fought/intended to be fought by the subject of the verb marked with the case marker 'oṭu'. Perhaps Nātțār and Piḷai were influenced by Rā. Rākavaiyañkār and Irājakōpālāryann, who interpreted Pānan as an ally of Kațti in their edition. Hart (2015, p. 232) has followed Nāttār's interpretation.

14 See the Cōmacuntaranār edition of the Akanān̄ūru.

15 Wilden has chosen the reading titti 'snack'. I prefer the reading tirrri 'meat' as do earlier editions of the Akanānūru. Moreover, titti is used nowhere else in the Cankam literature in the sense of food and tirri is related to tin 'eat' in Dravidian Etymological Dictionary Second Edition (DEDR hereafter) entry 3263 and titti is not. vayiriya mākkal pan amaittu elīi 'the Vayiriyar bards having set the melody and making music'.

17 Wilden has not compared the present text pānann nal nātțu with the text nal vēl pānan nal nātțu in Akanānūuru 325.27 which means 'in the good land of Pānan with the good spear' where Pānan is clearly a warrior and chief as he has a spear and possesses the good land.

18 In the Cankam tradition, the term vēntar in the poem could only refer to the kings of the Cēra, Cōla, and Pāṇtiya dynasties.

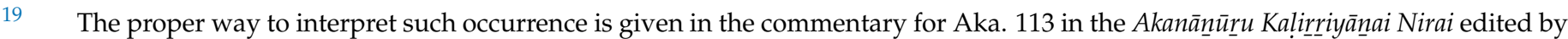
Vē. Civacuppiramaniyan. (In addition to earlier manuscripts, this edition also used a paper manuscript with commentaries for 170 poems discovered in the Tākțar U. Vē. Cāminātaiyar Nūl Nilaiyam during the publication process for this 1990 publication.) Here is the relevant excerpt from the commentary for Akanānūuru 113.17, which mentions Pānann, the chief.

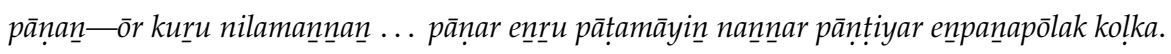

Pānan_-a minor king or chief ... if the reading is pāṇar, interpret it like Nan̄nar and Pāṇtiyar, where Nannnar and Pāntịyar refer to the dynasties of Nannnan chiefs and Pāṇtiyan kings, respectively, or their warriors.

Akanānūuru 113, and 325 refer to a chief by the name 'Pānan'. Akanānūuru 155 refers to 'Pānātu' the land of Pān, which the

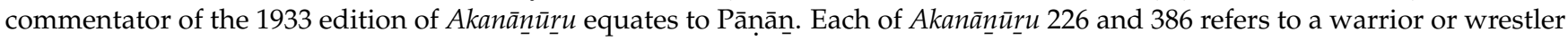
referred to as Pānan.

21 In the transliteration system followed in this essay, the name is Rākavaiyañkār. What Mahadevan refers to as Raghavaiyangar (1933) is the same as the 1933 edition of Akanānūuru by Rākavaiyañkār and Irājakōpālāryan. 'Aka.' is abbreviation for the Akanān-ūru.

23 This is similar to the land of the Cōlas mentioned in Akanāñūru 201.12-13 as cōlar veṇnel vaippin nal nātu 'the good land of the Cōlas with areas growing white paddy'

24 The Periyapurānam (PP) mentions two places, Pātaliputtiram, and Tiruppātirippuliyūr but never identifies one with the other (1303.1 and 1396.4). In fact, PP does not clearly state where Pātaliputtiram is located, either in South Arcot district or elsewhere. Modern scholars like Rā. Pi. Cētuppillai (aka R. P. Sethu Pillai) have identified Pātaliputtiram with Tiruppātirippuliyūr near Cuddalore on the Bay of Bengal (Cētuppillai 2007, p. 228). This identification is based on the fact that Tamil name 'Pātiri' and Sanskrit 'Pătali" refer to the same tree with the botanical name Bignonia suaveolens or Sterospermum chelonoides (the tree bearing the trumpet-flower). Additionally, the god in the temple at Tiruppātirippuliyūr is called Pātalīśvarar with the temple tree being Pātiri. However, the Pātiri tree is not confined to one location in Tamil Nadu and there are many villages with the name Pātiri in Tamil Nadu. There is a hilly village called Pātiri (Pin Code 635703) in Tiruvannamalai district approximately $50 \mathrm{~km}$ by road to the west of Pōlūr in Javvadu Hills. We have one Pātiri approximately two km from Vandavasi sharing the same Pin Code 604408. We also have a Mel Pātiri (west Pātiri) in the same Pin Code. We have a village called Pātiri (Pin code 603201) approximately 23 
$\mathrm{km}$ southeast of Vandavasi. Additionally, there is a village near Acharapakkam in Chengalpattu district called Pātiri too. Like the place names associated with the above locations, a place name Pātiri would offer better possibilities for direct translation into Sanskrit as Pātalika (with the addition of suffix ka) than Tiruppātirippuliyūr. Given all these possibilities, we do not have to accept the location near Cuddalore as the ancient location of Pātalikā. Consequently, Pātalikā could have been located in the region known later as Perumpāṇappāṭi or Vānakōppāṭi. One does not have to worry about the Pānar dynasty controlling an area as far south as Tiruppātirippuliyūr.

25 Although Ramachandran cites Epigraphia Indica, vol. 8, p. 30 as his source for the information, the correct page number should have been 35. Here Mayūraśarman is said to have levied taxes on the Great Bāna, but there is no mention of the Bāna being an ally of Mayūraśarman.

26 This article follows the University of Madras Tamil Lexicon system of transliteration. However, often epigraphists and historians transcribe Tamil words and do not transliterate according to the University of Madras Tamil Lexicon system. In quoting their work, the text in the source document is not changed. Here, Perumbanar mentioned by Chopra, Ravindran, and Subrahmanian is the same as Perumpāṇar according to our system of transliteration. Additionally, Sanskrit vocalic $r$ in Bṛhadbāṇa has been rendered as $r i$ here. In excerpts quoted from Epigraphia India articles it is rendered as $r i$ as given in the publications. Elsewhere, it is rendered as $r$.

My translation is based on Po. Vē. Cōmacuntaran̄ār, a modern commentator, who explains those lines as:

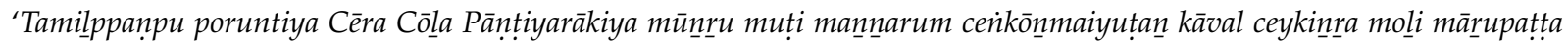

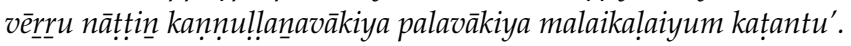

It should be noted that long after the Tamil confederacy ceased to exist, the Tamil land was denoted by the term trairājya in Sanskrit inscriptions like the Kēndūr Plates of Kīrttivarman II (Epigraphia Indica, vol. 9, pp. 202-5). Pathak (Epigraphia Indica, vol. 9, p. 205) has translated trairājya in South Indian Sanskrit inscriptions and literary texts as "the confederacy of three kings". Pathak quotes a commentary of the Ādipurāna (XXX, 35) which explains trairājya as meaning "Chola, Kerala and Pāndya". The Pārttivacēkarapuram śālā grant of 866 CE specifies that the students of the śālā should be learned in trairājya vyavahāra., i.e., administrative matters of the Cēra, Cōla, and Pāntiya kingdoms (The Tamil Varalatru Kazhagam 1967, A-5 and A-15). There were administration officials under the Cōlas with the title Trairājyaghatikā Madhyasthan (South Indian Inscriptions, vol. 30, no. 117, pp. 98-99) in 961 CE. The fact that the royal officials of the Pāntiya, and Cōla kingdoms were continued to be given the title

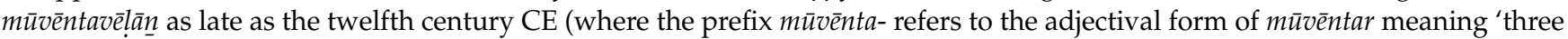
Tamil kings') as in South Indian Inscriptions, vol. 14, no. 233, p. 137, i.e., more than a millennium after the three kingdoms ceased to have any semblance of a confederacy, indicates the vestiges of a tradition that must have been developed during the days of the confederacy. The Vakkaleri Plates of Kīrtivarman II also mention trairājya (Epigraphia Indica, vol. 5, p. 203). The Jejuri grant also mentions trairājya (Epigraphia Indica, vol. 19, p. 64). A discussion of the significance of the term trairājya is presented by Tieken (2001, p. 134).

Jayaswal and Banerji prefer the interpretation of terasa-vasa-satikam as 113 years while some other scholars interpret it as 1300 years. See Epigraphia Indica, vol. 20, p. 88, n. 5.

Sastri (1987, p. 144) says, 'A long historical night ensues after the close of the Śangam age. We know little of the period of more than three centuries that followed. When the curtain rises again towards the close of the sixth century A.D., we find that a mysterious and ubiquitous enemy of civilization, the evil rulers called Kalabhras (Kalappālar), have come and upset the established political order which was restored only by their defeat at the hands of the Pāndya and Pallavas as well as the Chālukyas of Bādāmi. Of the Kalabhras, we have as yet no definite knowledge; from some Buddhist books we hear of a certain Accutavikkanta of the Kalabhrakula during whose reign Buddhist monasteries and authors enjoyed much patronage in the Chola country ... The Cholas disappeared from the Tamil land almost completely in this debacle, though a branch of them can be traced towards the close of the period in Rayalaseema-the Telugu-Chodas ... ' The latest work on Kalabhras is by Gillet (2014), who summarizes the work of many scholars after Sastri, who have tried to trace the origin of the Kalabhras. She is skeptical about the Kalabhras occupying the Pāṇtiya kingdom. However, she has left out an important work by Kācinātan (1981), who discusses a ca. ninth-century inscription at Ponn_ivāṭi that mentions a ruler of the Konku region, kali niruva(pa) kalvan āina kōkkanțan iravi ‘King Kaṇtan Ravi alias Kali king Kalvann'. Based on this inscription, he equates the Kalabhras with the lineage of Kalvar mentioned in Akanānūuru 61.11 (Kācinātan_ 1981, p. 14). For more details regarding this inscription, see Epigraphia Indica, vol. 38, pp. 37-39. Additionally, Gillet has not considered Kallātam 57.12-13 of the tenth century CE, and Periyapurānam 991.2 of the twelfth century, which mention a king from Karnataka ruling over Madurai. These are discussed by Kācinātan (1981, pp. 20-22). The updated date of seventh century for Mālēpāḍu plates follows Sastri (Epigraphia Indica, vol. 27, p. 251).

32 The important expression in the plates in this connection is 'trairājya-sthitim=ātmasāt-krtavatah. Even though it comes several centuries after Khāravela, what Mālēpādu plates suggest is the possible historical fact of Karikālā becoming the sole overlord of the whole Tamil region at a cost to the confederacy of the three Tamil kingdoms mentioned earlier. Indeed, these plates may offer an independent corroboration of the existence of the confederacy and the possible reason for its defeat by Khāravela. The 'three kings' in the quote above is the translation of Sanskrit 'trairājya' in the inscription attesting to the earlier state of Tamil confederacy. It should be noted that the Telugu Cōla claims descent from the Tamil king Karikāla. As seen earlier, Māmūlañār also has mentioned the joint defense of the northern border of the Tamil region by the three Tamil kings in Akanānūru 31. We know that 
Karikāla is praised by Māmūlan̄ār in Akanān̄ūru 55 as having won a fierce battle against the Cēra king. Thus, Māmūlan̄ār must have witnessed in his lifetime the Tamil confederacy in operation as well as its possible weakening or collapse under Karikāla. This suggests that Khāravela either defeated a weakened Tamil confederacy or the confederacy's defeat led to an internecine struggle that ultimately led to Karikāla becoming the sole overlord of the Tamil country. The corrected date of fifth century is noted in the errata.

Kiruṣnakiri Māvatțak Kalvețtukal, p. 29. The name Perumpānavilavaraicar < perum+pāna+v+ila+v+araicar, where -v- is due to sandhi and ilavaraicar indicates a prince. Here, pāna functions as an adjective. The name Perumpānaraicar $<$ perum+pān+araicar. Here, $p \bar{a} n$ functions as an adjective.

The letters 'car' are missing in the inscription but can be inferred.

Epigraphia Indica, vol. 8, p. 28.

Periyapurānam 3773.3. Pānanāār is the honorific form of the masculine singular form, Pānañ.

Periyapurānam 2159.3. According to legends associated with the founding of Jaffna or Yālppānam in northern Srī Lanka, a Yālppānann meaning 'a Pānan playing a lute' came from India and performed before the local king, who presented him with some uninhabited land in northern Sri Lanka. After receiving the land, the bard returned to India and encouraged some other bards to go to Sri Lanka and settle in the land the bard had received. Over time, that settlement grew to be known as Yālppānam. The Tamil Saint Arunakirinātar of the fifteenth century CE conflated this bard with Saint Tirunīlakaṇta Yālppāna Nāyanāar and called Yālppaṇam as Yālppānāyan (Yālppāṇ+Nāyann) Pattinam (Rasanayagam 1984, pp. 245-49). This legend also supports the tradition of the bards receiving land as gift.

However, it should be noted that Palkuriki Sōmanātha in his Basavapurānam mentions a Bāna, who is depicted more along the lines of Bānāsura than Bānabhadra (Rao and Roghair 1990, p. 160). However, Sōmanātha's work came at least a century later. So, we cannot equate his ideas with whatever the author of the inscription had in $1101 \mathrm{CE}$.

Handwritten notebook of A. Subramanian, Lecturer in Veena, Banaras Hindu University, containing Harikesanallur L. Muthiah Bhagavatar's compositions available at Music Research Library, Chennai. 1946. It can be downloaded from http:/ / musicresearchlibrary.net/omeka/items/show/1822 (accessed on 14 November 2021).

Vikramachola was not the king who issued the grant. See South Indian Inscriptions, vol. 5, no. 705.

Although we come across persons with titles beginning with Bāna- and Vāna- even up to the sixteenth century CE, their real affiliation to the early Bāṇas is suspect. There is a thirteenth-century CE Pāṇtiya Māravarman Kulacēkara Tēvar inscription in Tirutturaippūnṭi that mentions a Kaikkōlar by the name Tiruvānṭārāña Cīñ kanamarāyarāña Vānarāyar (a Kaikkōlar named Tiruvāntār alias Cinkanamārāyar alias Vānarāyar) (Tirutturaippūntik Kalvețtukal, p. 108). Cīnnkana was the name of a general of the Hoysala king Somēśvara killed before Māravarman Kulacēkara began his reign in 1268 CE (Sastri 1987, pp. 215-16). Kaikkōlars were part of elite Cōla military units. In post-Cōla times, they gradually shed their association with military units and emerged as an occupational status group according to Ali (2007, p. 509). Clearly, this Kaikkōlar was not affiliated with the Bāna chiefs by descent. He had been given or assumed the title Vānarāyar. Because of problems like these, Orr (2018, p. 347) says, “Indeed, we cannot be sure of the actual filiation among the rulers who took up the titles and claims to fame of the Bānas in successive times and various places, although a good deal of scholarship has in the past been devoted to aspects of the political history of the Bānas and the clan's relationships with the kings belonging to South India's major dynasties".

For details about this story, see (Cane 2019, p. 35).

Ali (2000, pp. 185-89) sees an influence of Rāstrakūtas from the eighth century in the claims of the Cōlas of Tanjavur and the Pāntiyas of Madurai to belong to Solar and Lunar descents, respectively, with an objective of claiming paramount overlordship of the world. However, as noted earlier, Punyakumāra, a Telugu Cōla of the seventh century, claimed to belong to the race of the Sun.

South Indian Inscriptions, vol. 2, parts 3\& 4, p. 386. The Mahābhārata's Śibi belonged to the Lunar lineage. However, the Cōlas claiming to belong to the Sōlar lineage included Śibi in the Sōlar race, since he was already mentioned in Puranān̄ūru 37, 39, 43, and 46.

South Indian Inscriptions, vol. 3, no. 42, p. 91; Ramachandran (1931, p. 305)

kulotbhava is corrected as kulodbhava in other inscriptions.

While Kielhorn (Epigraphia Indica, vol. 3, pp. 74-79) has called him Vikramāditya II, Ramachandran (1931, p. 309) has corrected it to Vikramāditya III based on updated information up to 1931.

Pātāla is netherworld.

Based on Cilappatikāram 6.39-63 and its commentary by Ațiyārkkunallār. Explanations within parenthesis are based on Ațiyārkkunallār's commentary.

That Kṛ̣ṇa performed this dance after killing Bānāsura is Aṭiyārkkunallār's explanation. The Arumpatavurai, the earlier commentary, does not say anything about this dance. In fact, Iḷankō Aṭikaḷ's own text allows for the interpretation that Kṛ̣na performed two dances in the capital of Kamsa-one after killing the elephant sent by Kamsa and the other after killing a demon. In the Harivaṃśa some seers are supposed to say to Kṛ̣na that Cānura, the wrestler, was a Dānava or Asura. Moreover, according to the Harivaṃśa, Bāṇāsura is not killed by Kṛ̣na. Kṛ̣ṇa only cuts all his arms except two and spares his life due to Śiva's request. 
However, it should be noted that none of the dances performed by Kṛnna in Kamsa's and Bāna's cities are mentioned in the Sanskrit texts. So, Ațiyārkkunallār might have been mistaken about the locale of the Mal dance or he could be drawing on a different narrative tradition.

52 Pilllai and Ponipās (1966, pp. 16-18). Although not explicitly stated in the Puranānūuru, according to Tamil tradition, the three Tamil kings did not defeat Pāri in battle. They killed him by treachery. In his commentary on Puranānnūru 108, Auvai Turaicāmi Pillai says that the Tamil kings realized that waging war against Pāri and defeating him was difficult. So, they disguised themselves as suppliants and solicited Pāri as a gift. Following the righteous conduct of alleviating the poverty of solicitors, Pāri went with them and was killed by them. Additionally, in his commentary on Puranān̄ūru 110, Auvai Turaicāmip Pillai says, "Kapilar kūriyatu pōlavō, atu pōlvatoru cūlcciyinaiyo avarkal ceytu Pāriyaik konranar enpa" meaning "They say that they [the three kings] did either as Kapilar said or engaged in a similar treachery and killed Pāri.' Pilllai and Ponipas say that the three kings disguised themselves as bards and performed before Pāri. At the end of the performance Pāri asked what the bards wanted as gifts, and they asked for his kingdom and his life. Pāri offered his own kingdom and life to the three disguised kings overruling the objections from his warriors and people. Then, the three kings killed him. In a literary poetic work called the Pāri Kātai by Rā. Rākavaiyañkār, the famous Tamil scholar, who was an editor of the Akanān̄üru, says that the three kings sent a soldier disguised as a bard to sing before Pāri. After the performance, when Pāri asked the disguised soldier what gifts he wanted, he asked for Pāri himself. Pāri gave himself to the disguised soldier and followed him. The soldier took Pāri to the center of the gathered armies of the three kings. There the three kings killed him (Pāri Kätai 412-28). The important thing to note here is that there was treachery involving disguise to defeat a philanthropist. This is what I find important in the story of Pāri because in the story of Bali and Vāmana too, we have Viṣnu, in effect, disguised as a Brahmin dwarf and deceptively asking for land that is measured in three strides. However, when Bali granted that request, the dwarf Vāmana grew into his giant cosmic form and took away Bali's sovereignty and exiled him to the netherworld. Pāri lost his sovereignty due to his enemies using treachery to exploit his sense of duty towards the bards. Bali lost his sovereignty due to his enemy, Viṣnu, using treachery to exploit his sense of duty towards philanthropy towards the Brahmins. In both cases, the kings honored their personal code of philanthropy even when it meant a great loss to themselves personally.

53 Akanān̄ūru 196.1-5 (Cōmacuntaran̄ār Edition).

54 Aiǹkurunūru 49 (Cāminātaiyar Edition).

\section{References}

\section{Primary Sources}

Ainkurūūūru Mūlamum Palaiyavraiyum. 1980. ed. U. Vē. Cāminātaiyar. Cēnnñai: Tākṭar U. Vē. Cā Nūl Nilaiyam.

Ainkurunūru Mūlamum Vilakkavuraiyum. Part III. Mullai. 1958. ed. Auvai Cu. Turaicāmip Piḷai. Madurai: Annamalai University Tamil Series.

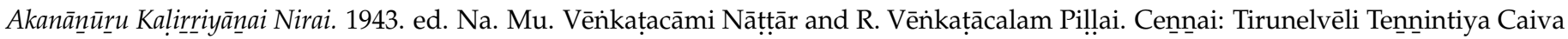
Cittāṇta Nūrpatippuk Kalakam

Akanān̄ūru Kaḷirriryānai Nirai. 1970. ed. Po Vē Cōmacuntaran̄ār Elutiya Patavurai Viḷakkavuraikalutạnn. Madras: The South India Saiva Siddhanta Works Publishing Society.

Akanān̄ūru Kalịrrriyāñai Nirai. 1990. ed. Vē. Civacuppiramaṇiyañ. Cennnai: Ṭākṭar U. Vē. Cāminātaiyar Nūl Nilaiyam.

Akanān̄ūru Kalịrriyānai Nirai: A Critical Edition and an Annotated Translation (3 volumes). 2018. ed. Eva Wilden. Pondicherry: École française d'Extrême-Orient and Tamilmann Patippakam

Akanānūuru Manimiṭai Pavalam, Nittilakkōvai. 1977. ed. Po Vē Cōmacuntaran̄ār Elutiya Patavurai Vilakkavuraikalutañ. Cennnai: The South India Saiva Siddhanta Works Publishing Society.

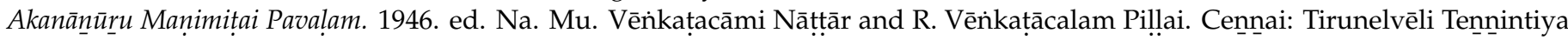
Caiva Cittānta Nūrpatippuk Kalakam.

Akanān̄ūru Maṇimițai Pavalam. 1990. è. Vē. Civacuppiramaṇiyan. Cennnai: Ṭākțar U. Vē. Cāminātaiyar Nūl Nilaiyam.

Akanānūūru Mūlamum Palaiya Uraiyum. 1933. ed. Rā. Rākavaiyañkār and Irājakōpālāryan. Mayilāppūr: Kampar Pustakālayam.

Akanān̄ūru Nittilakkōvai. 1944. ed. Na. Mu. Vēnkațacāmi Nāțāār and R. Vēnkațācalam Piḷlai. Cennnai: Tirunelvēli Tennnintiya Caiva Cittānta Nūrpatippuk Kalakam

Akanān̄ūru Nittilakkōvai. 1990. è. Vē. Civacuppiramaniyañ. Cennnai: Ṭākṭar U. Vē. Cāminātaiyar Nūl Nilaiyam.

Annual Report for the Mysore Archaeological Department for the Year 1941. 1942. Mysore: University of Mysore.

Annual Reports on Indian Epigraphy. 1906-1910. New Delhi: Archaeological Survey of India, 1986.

Annual Reports on Indian Epigraphy. 1940-1941. New Delhi: Archaeological Survey of India, 1986

Ceñkam Națukarkal. 1972. ed. Irā. Nākacāmi. Cennnai: Tamilnāṭu Aracu Tolporul Āyvutturai.

Cilappatikāra Mūlamum Arumpatavuraiyum Ațiyārkkunallāruraiyum. 1985. ed. U. Vē. Cāminātaiyar. Tañcāvūr: Tamilnppalkalaikkalakam.

Cirupānārrruppațai. 2000. ed. Po Vē Cōmacuntaranāā. Cennnai: The South India Saiva Siddhanta Works, Publishing Society.

Dravidian Etymological Dictionary. Second Edition. 1984. Thomas Burrows and Murray B. Emeneau. Oxford: Clarendon Press.

Epigraphia Indica. 1892-1978. 42 volumes. Calcutta/New Delhi: Archaeological Survey of India.

Harivamsha (Krishna's Lineage: The Harivamsha of Vyāsa's Mahābhārata.) 2019. Translated by Simon Broadbeck. New York: Oxford University Press. 
Kalittokai: Naccinnārkkiniyarurai. 1969. ed. Po Vē Cōmacuntaranāàr. Madras: The South India Saiva Siddhanta Works Publishing Society. Kallātam with Commentary by M. Nārāyanavēelup Pillai. 1994. Cennai: Mullai Nilaiyam.

Kiruṣnakiri Māvaț̣ak Kalvețtukal. 2007. ed. Irācakōpāl and Ca. Kiruṣnamūrtti. Chennai: Tamilnāṭu Aracu Tolliyalturai.

Kōyamputtūur Māvatțak Kalvețtukal. 2006. ed. Ti. Pa. Śrītar. Cennnai: Tamilnāṭu Aracu Tolliyalturai.

Kuruntokai. $3 d$ ed. 1955. ed. U. Vē. Cāminātaiyar. Cennnai: Kapīr Accukkūțam.

Kuruntokai: A Critical Edition and an Annotated Translation (3 volumes). 2010. Eva Wilden Eva. Pondicherry: École française d'ExtrêmeOrient and Tamilmann Patippakam.

Mahābhārata. Volume 2. 1981. Translated and edited by J. A. B. van Buitenen. Chicago: The University of Chicago Press.

Maṇimēkalai. 1965. ed. U. Vē. Cāminātaiyar. Cennnai: Kapīr Accukkūțam.

Maturaik Kāñci. 1977. ed. Po Vē Cōmacuntaranār. Madras: The South India Saiva Siddhanta Works Publishing Society.

Mysore Archeological Report.

Narrinai Mūlamum Vilakkavuraiyum. 1966. ed. Auvai Cu. Turaicāmip Pillai. Cennnai: Aruṇā Paplikēṣañs.

Narrinai Mūlamum Vilakkavuraiyum: 201 Mutal 400 Varai. 1968. ed. Auvai Cu. Turaicāmip Piḷai. Cennnai: Aruṇā Paplikēṣanns.

Pāri Kātai. $2 d$ ed. 1978. Rā. Rākavaiyañkār. Aṇnāmalainakar: Aṇnāmalaip Palkalaikkalakam.

Patirruppattu: Arāycciyurai. Pakuti I E II. Palaiyavurai Oppumaippakuti Palavakai Arāyccik Kurippukkal Mutaliyavarrrutan Panțitar Cu. Arulampalavan̄ār Iyarriyatu. 1965. Yālppāṇam: A. Civān̄antanātan.

Pattuppātțu Mūlamum Maturaiyāciriyar Pārattuvāci Naccinnārkkinniyaruraiyum. 1931. ed. U. Vē. Cāminātaiyar. Cennnai: Kēcari Accukkūṭam. Periyapurānam Ennnum Tiruttonțar Purānam. 1964-1975. ed. C. K. Cuppiramaṇiya Mutaliyār. Koyamputtūr: Kōvait Tamil̄ Cañkam.

Peruntokai. 1935-1936. Mu. Irākavaiyañkār. Madurai: Madura Tamil Sangam

Porunarārrruppațai. 2001. ed. Po Vē Cōmacuntaranāā. Cennnai: The South India Saiva Siddhanta Works, Publishing Society.

Puranān̄ūru: 1-200 Pāțtukkal. 1996. ed. by Auvai Cu. Turaicāmip Piḷai. Cennnai: The South India Saiva Siddhanta Works Publishing Society.

Puranān̄ūru: 201-400 Pātțukkal. 1991. ed. by Auvai Cu. Turaicāmip Piḷai. Cennnai: The South India Saiva Siddhanta Works Publishing Society.

Purapporul Veṇpāmālai. 10th ed. 1994. ed. Po Vē Cōmacuntaranār. Cennnai: The South India Saiva Siddhanta Works, Publishing Society. South Indian Inscriptions. 1890-2011. 30 volumes. Archaeological Survey of India.

Tamil Lexicon. Six Volumes and Supplement. 1924-39. ed. S. Vaiyapuri Pillai. Madras: University of Madras.

Tarumapuri Kalvețtuka! (Mutal Tokuti). 1975. ed. Irā. Nākacāmi. Cennnai: Tamilnāṭu Aracu Tolporul Āyvutturai.

Tirukkural: Parimēlalakar Urai. 1996. Cenn_ai: Kañkai Puttaka Nilaiyam, 1996.

Tirutturaippūnțtik Kälvețtukal. 1978. ed. İāā. Nākacāmi. Cennnai: Tamilnātu Aracu Tolporul Āyvutturai.

Tiruvālavāyuṭaiyār Tiruvilaiyātararpurāṇam. 1972. ed. U. Vē. Cāminātaiyar. Cennnai: Śñ̄ Tiyākarāca Vilāca Veliyītu.

Tolkāppiyam. 1993. With the Commentary by Puliyūrk Kēcikan. Cennnai: Pārinilaiyam.

\section{Secondary Sources}

Ali, Daud. 2000. Royal eulogy as World History: Rethinking copper-plate inscriptions in Cola India. In Querying the Medieval: Texts and the History of Practices in South Asia. Edited by Ronald Inden, Jonathan Walters and Daud Ali. New York: Oxford University Press, pp. 165-229.

Ali, Daud. 2007. The Service Retinues of the Chola Court: A Study of the Term Velam in Tamil Inscriptions. In Bulletin of the School of Oriental and African Studies. London: University of London, vol. 70, pp. 487-509.

Arunachalam, M. 1977. Harijan Saints of Tamilnadu. Tiruchitrambalam: Gandhi Vidyalayam.

Broadbeck, Simon. 2019. Krishna's Lineage: The Harivamsha of Vyāsa's Mahābhārata. New York: Oxford University Press.

Cane, Nicolas. 2019. Temples, Inscriptions and Historical (Re)construction: The 'Epigraphical Persona' of the Cōla Queen Cempiyan Mahādevī (Tenth Century). Bulletin de L'Ecole Française D'Extrême-Orient 105: 27-60. [CrossRef]

Cētuppillai, Rā. Pi. 2007. Tamil Inpam, 15th ed. Cennnai: Palan_iyappā Piratars. First published in 1948.

Chopra, P. N., T. K. Ravindran, and N. Subrahmanian. 1979. History of South India: Vol. I: Ancient Period. New Delhi: S. Chand \& Company Ltd.

Fisher, Elaine M. 2017. Hindu Pluralism: Religion and the Public Sphere in Early Modern South India. Oakland: University of California Press.

Gillet, Valerie. 2014. The Dark Period: Myth or reality? The Indian Economic and Social History Review 51: 283-302. [CrossRef]

Gopalachari, K. 1941. Early History of the Andhra Country. Madras: University of Madras.

Hart, George L. 1975. Ancient Tamil Literature: Its Scholarly Past and Future. In Essays on South India. Edited by Burton Stein. Honolulu: The University Press of Hawaii, pp. 41-63.

Hart, George L. 2015. The Four Hundred Songs of Love. Pondicherry: Institut Français De Pondichéry.

Hart, George L., and Hank Heifetz. 1999. The Four Hundred Songs of War and Wisdom. New York: Columbia University Press.

Hospital, Clifford. 1984. The Righteous Demon: A Study of Bali. Vancouver: University of British Columbia Press.

Ilanikumaran, Irā. 1987. Pānar. Citamparam: Maṇivācakar Patippakam.

Jain, Sagarmal. 2007. Jain Litertature. 14th Biennial Jaina Convention Souvenir. New Jersey: Edison, pp. 129-32.

Kācinātan, Națana. 1981. Kalappirar. Cennai: Tamilnāțu Aracu Tolporul Āyvutturai.

Kailasapathy, K. 1968. Tamil Heroic Poetry. Oxford: Clarendon Press. 
Kersenboom-Story, Saskia. 1981. Virali (Possible sources of the devadāsi tradition in the Tamil Bardic period). Journal of Tamil Studies, International Institute of Tamil Studies 19: 19-41.

Krishnamurti, Bhadriraju. 2003. The Dravidian Languages. Cambridge: Cambridge University Press.

Ludden, David E. 1996. Caste Society and Units of Production in Early-Modern South India. In Institutions and Economic Change in South Asia. Edited by Burton Stein and Sanjay Subrahmanyam. Delhi: Oxford University Press, pp. 105-33.

Mahadevan, Iravatham. 2003. Early Tamil Epigraphy: From the Earliest Times to the Sixth Century A.D. Chennai: Cre-A and Cambridge: Harvard University Press.

Nagaswamy, R. 2012. Mirror of Tamil and Sanskrit. Chennai: Tamil Arts Academy.

Orr, Leslie. 2018. The Bhakti of the Bānas. In Clio and Her Descendants: Essays for Kesavan Veluthat. Edited by M. V. Devadevan. New Delhi: Primus Publications, pp. 347-86.

Palaniappan, Sudalaimuthu. 2008. On the Unintended Influence of Jainism on the Development of Caste in Post-Classical Tamil Society. International Journal of Jaina Studies 4: 1-65.

Palaniappan, Sudalaimuthu. 2016. Hagiography versus History: The Tamil Pānar in Bhakti-Oriented Hagiographic Texts and Inscriptions. In Archaeology of Bhakti: Royal Bhakti, Local Bhakti. Edited by Emmanuel Francis and Charlotte Schmid. Pondicherry: Institut Français de Pondichéry and École française d'Extrême-Orient, pp. 303-46.

Parthasarathy, R. 1993. The Cilappatikāram of Ilanikō Ațikal: An Epic of South India. New York: Columbia University Press.

Pillai, Es. Vaiyāpuri, ed. 1967. Cañka Ilakkiyam. Cennnai: Pāri Nilaiyam.

Pịḷai, R. L. Ārōkkiyam, and G. Ponipās. 1966. Uyirk̄kotai Vallalkal. Tūttukkuṭi: Tamil Ilakkiyak Kalakam.

Rajagopalan, N. 1992. Another Garland: Biographical Dictionary of Carnatic Composers \& Musicians (Book II). Madras: Carnatic Classicals.

Ramachandran, T. N. 1931. The Bānas. The Journal of Oriental Research Madras 5: 299-315.

Rao, Velcheru Nararayana, and Gene H. Roghair. 1990. Śiva's Warriors: The Basava Purāna of Palkuriki Sōmanātha. Princeton: Princeton University Press.

Rasanayagam, Mudaliyar C. 1984. Ancient Jaffna. New Delhi: Asian Educational Services.

Richman, Paula. 1988. Women, Branch Stories, and Religious Rhetoric in a Tamil Buddhist Text. Syracuse: Syracuse University.

Sastri, K. A. Nilakanta. 1987. A History of South India from Prehistoric Times to the Fall of Vijayanagar, 4th ed. Madras: Oxford University Press.

Subramanian, A. 1946. Handwritten Notebook Containing Harikesanallur L. Muthiah Bhagavatar's Compositions. Chennai: Music Research Library.

Taylor, McComas. 2021. The Viṣnu Purāna: Ancient Annals of the God with Lotus Eyes. Acton: Australian National University.

Thani Nayagam, Xavier S. 1995. Collected Papers of Thani Nayagam Adigalar. Madras: International Institute of Tamil Studies.

Thapar, Romila. 2002. Early India: From the Origins to AD 1300. Berkeley: University of California Press.

The Tamil Varalatru Kazhagam. 1966. Thirty Pallava Copper-Plates. Madras: The Tamil Varalatru Kazhagam.

The Tamil Varalatru Kazhagam. 1967. Ten Pandya Copper-Plates. Madras: The Tamil Varalatru Kazhagam.

Thurston, Edgar. 1909. Castes and Tribes in Southern India. Madras: Government Press, vol. 6.

Tieken, Herman. 2001. Kāvya in South India: Old Tamil Cankkam Poetry. Groningen: Egbert Forsten.

Varatarācan, Ve. 1973. Tamillppānar Vālōum Varalārum. Cennnai: Paṇnạn Patippakam.

Vētācalam, Ve. 1987. Pāntitiya Nātțil Vānātirāyarkal. Madurai: Tolporul Tolilnuṭpap Paṇiyālar Paṇpātṭukkalakam.

Zvelebil, K. V. 1975. Tamil Literature. Leiden/Koln: E. J. Brill.

Zvelebil, Kamil V. 1992. Companion Studies to the History of Tamil Literature. Leiden: E. J. Brill. 